\title{
The Royal Imagery of Medieval Serbia
}

\author{
Branislav Cvetković
}

\section{1 \\ Serbian Royalty: Origins and Related Issues}

The variegated art forms created during the Middle Ages in the Balkans, despite being only partially preserved, offer a wealth of material pertaining to royal portraiture. The extant corpus from medieval Serbia significantly surpasses in numbers that of all neighbouring regions, ${ }^{1}$ including portrayals of sovereigns that provide abundant political, ecclesiastical, and ideological data and reflect the complex and often volatile late medieval history of this part of Europe. ${ }^{2}$ Having said this, I wish to stress that medieval Serbian images of royalty cannot be properly understood by dwelling solely on their visual and material elements; the path towards understanding these images must rely firmly on written data, from hagiographies to diplomatic material, ${ }^{3}$ which are valuable sources that can do much to explain the content and context of the official imagery of medieval Serbian royalty. ${ }^{4}$ However, due to limited space,

1 For a general overview of Serbia, see: The History of Serbian Culture, ed. Pavle Ivić (Edgware, 1995); Sima Ćirković, The Serbs (Malden, 2004). See also: Miloš Blagojević, Srbija u doba Nemanjića [Serbia in the Nemanjić era] (Belgrade, 1989); Jovanka Kalić, Srbi u poznom srednjem veku [Serbs in the Late Middle Ages] (Belgrade, 1994).

2 For earlier periods of medieval Serbia, see: Istorija srpskog naroda 1 [History of the Serbian nation], ed. Sima Ćirković (Belgrade, 1981); Đorđe Bubalo, Srpska zemlja i pomorska u doba vladavine Nemanjića 1 [Serbian lands and the Littoral during the Nemanjić reign] (Belgrade, 2016). For the later ones, see: Istorija srpskog naroda 2 [History of the Serbian nation], ed. Jovanka Kalić (Belgrade, 1982); Momčilo Spremić, Despot Đurađ Branković i njegovo doba [Despot Đurađ Branković and his time] (Belgrade, 1994).

3 For a few syntheses of medieval Serbian hagiographic literature, see: Milan Kašanin, Srpska književnost u srednjem veku [Serbian literature in the Middle Ages] (Belgrade, 1975); Dimitrije Bogdanović, Istorija stare srpske književnosti [History of old Serbian literature] (Belgrade, 1980); Gerhard Podskalsky, Theologische Literatur des Mittelalters in Bulgarien und Serbien 865-1459 (Munich, 2000).

4 For the ideology of the medieval Serbian state, see: Dimitrije Bogdanović, "Politička filosofija srednjovekovne Srbije. Mogućnosti jednog istraživanja," [Political philosophy of medieval Serbia. Possibilities of research] Filosofske studije 16 (1984), 7-28; Boško Bojović, L'Idéologie monarchique dans les hagio-biographies dynastiques du Moyen Âge serbe (Roma, 1995); Smilja Marjanović-Dušanić, Vladarska ideologija Nemanjića. Diplomatička studija [Royal ideology of the Nemanjić. A diplomatic study] (Belgrade, 1997); Andrija Veselinović, Država srpskih despota [State of the Serbian despots] (Belgrade, 20o6), pp. 38-61.

(C) BRANISLAV CVETKOVIĆ, 2022 | DOI:10.1163/9789004511583_007

This is an open access chapter distributed under the terms of the CC BY-NC 4.0uliceense; Cvetković - 9789004511583 Downloaded from Brill.com04/26/2023 01:38:08PM 
this survey can address only a portion of this expansive and well-researched material.

Since the earliest times, whether for economic, geographic, or dynastic reasons, medieval Serbian political theory and artistic production were imbued with norms and forms coming from both east and west of Europe. ${ }^{5}$ Through most of the turbulent late medieval period, in the religious and cultural spheres Serbian society looked predominantly to Byzantium as a role model. ${ }^{6}$ At the same time, in creating its core ideological framework, the Serbian elite established a series of cults honouring saintly rulers, ${ }^{7}$ a practice with origins in Western and Central Europe. ${ }^{8}$ In having themselves lavishly portrayed in various genres and media and for reasons of propaganda and piety, medieval Serbian rulers nevertheless borrowed from the Byzantine court, starting with the representational strategies of its aristocracy and extending later to the imperial regalia that adorned the images of the basileis in Constantinople. ${ }^{9}$ Indeed, the official portraits of Byzantine emperors and empresses came to be imitated in minute detail and sometimes even in terminology, manifesting

5 Gordana Babić, "Western Medieval and Byzantine Traditions in Serbian Art," in Tradition and Modern Society, ed. Sven Gustavsson (Stockholm, 1989), pp. 117-32; Branislav Cvetković, "Medieval Serbian Art between Byzantium and West," in Art and Its Role in the History: Between Durability and Transient-Isms, ed. Branko Jovanović et al. (Kosovska Mitrovica, 2014), pp. 311-28.

6 Bojana Krsmanović, and Ljubomir Maksimović, "Byzantium in Serbia - Serbian Authenticity and Byzantine Influence," in Sacral Art of the Serbian Lands in the Middle Ages, eds. Dragan Vojvodić, and Danica Popović (Belgrade, 2016), pp. 41-56. See also: Gilbert Dagron, Empereur et prêtre. Étude sur le 'césaropapisme' byzantin (Paris, 1996).

7 For some important studies, see: Danica Popović, Pod okriljem svetosti. Kult svetih vladara i relikvija u srednjovekovnoj Srbiji [Under the auspices of sanctity. The cult of holy rulers and relics in medieval Serbia] (Belgrade, 2006); Smilja Marjanović-Dušanić, Sveti kralj. Kult Stefana Dečanskog [The holy king. The cult of St. Stefan of Dečani] (Belgrade, 2007); Smilja Marjanović-Dušanić, "La mort et la sainteté du prince serbe," in La mort du prince de l'Antiquité à nos jours, eds. Jérémie Foa, Élizabeth Malamut, and Charles Zaremba (Aix-enProvence, 2016), pp. 61-78; Danica Popović, Riznica spasenja. Kult relikvija i srpskih svetih u srednjovekovnoj Srbiji [The treasury of salvation. The cult of relics and the Serbian saints in medieval Serbia] (Belgrade, 2018).

8 For a number of examples, see: Gábor Klaniczay, Holy Rulers and Blessed Princesses. Dynastic Cults in Medieval Central Europe (Cambridge, Eng. 2002).

9 See, for example: André Grabar, L'empereur dans l'art byzantin. Recherche sur l'art officiel de l'empire d'orient (Paris, 1936); Ioannis Spatharakis, The Portrait in Byzantine Illuminated Manuscripts (Leiden, 1976); Maria G. Parani, Reconstructing the Reality of Images. Byzantine Material Culture and Religious Iconography (11th-15th centuries) (Leiden, 2003); Jeniffer L. Ball, Byzantine Dress. Representations of Secular Dress in Eighth- to Twelfth-Century Painting (New York, 2005); Rico Franses, Donor Portraits in Byzantine Art: The Vicissitudes of Contact between Human and Divine (New York, 2018). 
the complex relationship of Serbia, lying deep in the Balkan hinterland, to the great political and cultural centres of Byzantium..$^{10}$ An interplay between imagery and written texts such as vitas, church offices, and charters is best documented from the Nemanjić dynasty and its immediate successors, the Lazarević and Branković dynasties, a period spanning the late 12th to the late 15th centuries. ${ }^{11}$ A number of extant images - including individual portraits, depictions of the members of the royal family as donors, and various scenes of historically or symbolically significant events in which distinctive royal figures are featured - display insignia and sumptuous costumes, mostly of Byzantine origin. ${ }^{12}$ Unfortunately, the textiles that once constituted the royal attire of medieval Serbia are today preserved only in traces. ${ }^{13}$

The most important body of royal images in Serbia consists of monumental portraits found in monastery and village churches, with not one example

$10 \quad$ For a few syntheses, see: Svetozar Radojčić, Portreti srpskih vladara u srednjem veku [Portraits of Serbian rulers in the Middle Ages] (Skopje, 1934); Vojislav J. Đurić, "Društvo, država i vladar u umetnosti u doba dinastije Lazarević-Branković," [Society, state and ruler in art during the Lazarević-Branković dynasty] Zbornik za likovne umetnosti Matice srpske 26 (1990), 13-41; Dragan Vojvodić, "Vladarski portreti srpskih despota," [The sovereign portraits of the Serbian despots] in Manastir Resava. Istorija i umetnost, [Resava Monastery. Its history and art] ed. Vojislav J. Đurić (Despotovac, 1995), pp. 65-98.

11 For a substantial survey, see: Vojislav J. Đurić, "Slika i istorija u srednjovekovnoj Srbiji," [Image and history in medieval Serbia] Glas Srpske akademije nauka i umetnosti 338 (1983), 117-33.

12 For sources on insignia, see: Smilja Marjanović-Dušanić, Vladarske insignije i državna simbolika u Srbiji od XIII do XVveka [The rulers' insignia and the state symbolism of medieval Serbia] (Belgrade, 1994).

13 See: Branislav Cvetković, "Textiles and Their Usage in Medieval Balkans: The Royal Context," in Clothing the Sacred. Medieval Textiles as Fabric, Form, and Metaphor, eds. Mateusz Kapustka, and Warren T. Woodfin (Berlin, 2015), pp. 33-52. See also: Jovan Kovačević, Srednjovekovna nošnja balkanskih Slovena. Studija iz istorije srednjovekovne kulture Balkana [Medieval costume of the Balkan Slavs. A study in history of the medieval culture of the Balkans] (Belgrade, 1953); Bojan Popović, and Branislav Cvetković, "Odevanje i kićenje," [Costume and adornment] in Privatni život u srpskim zemljama srednjeg veka, [Daily life in the Serbian lands of the middle ages] eds. Smilja MarjanovićDušanić, and Danica Popović (Belgrade, 2004), pp. 367-93; Branislav Cvetković, "Robes of Light and the 13th Century Frescoes in Boyana," in The Boyana Church Between the East and the West in the Art of the Christian Europe, ed. Bisserka Penkova (Sofia, 2011), pp. 198214; Bojan Popović, Srpska srednjovekovna vladarska i vlasteoska odeća [Serbian Medieval Royal and Nobility Costume] (Belgrade, 2020). 
preserved from palatine chapels or castles. Such images were regularly displayed in proximity to funerary ensembles and royal tombs. ${ }^{14}$ However, sculptures depicting members of the royal family - like those once placed on the west façade of the church of Holy Archangels Monastery near Prizren ${ }^{15}$ - were rare, as was the presence of royal imagery on icons ${ }^{16}$ and reliquaries. ${ }^{17}$ One must take into account the numismatic material, which through dozens of different types and thousands of specimens across museum and private collections provides substantive data on medieval Serbian royal imagery and insignia. ${ }^{18}$ Though far fewer seals have been preserved in comparison to coinage, these shed further light on the ideologies and iconographies in question..$^{19}$ Together, the coins and seals testify to certain extreme forms of appropriation of eastern and western types. One such example is connected to the first Serbian

14 For the seminal study, see: Danica Popović, Srpski vladarski grob u srednjem veku [The royal tomb in medieval Serbia] (Belgrade, 1992).

15 Danica Popović, "Predstava vladara nad 'carskim vratima' crkve Svetih arhanđela kod Prizrena," [Representation of sovereigns above 'imperial doors' of the church of Saint Archangels near Prizren] Saopštenja 26 (1994), pp. 25-36. On the rare instances of prostrate rulers, see: Dragan Vojvodić, “'Obavijen zemaljskom slikom.' O predstavama vizantijskih i srpskih srednjovekovnih vladara u proskinezi," ['Shrouded in earthly image.' On the images of Byzantine and Serbian medieval rulers in proskynesis] Crkvene studije 4 (2007), pp. 379-401.

16 On the icons in Bari and the Vatican, see: Bojan Miljković, "Nemanjići i Sveti Nikola u Bariju," [The Nemanjić and Saint Nicholas in Bari] Zbornik radova Vizantološkog instituta 44/1 (2007), 275-94; Branislav Cvetković, and Gordana Gavrić, "Kraljica Jelena i franjevci," [Queen Helen and the franciscans] in Jelena - kraljica, monahinja, svetiteljka, [Helen the queen, the nun, the saint] ed. Katarina Mitrović (Gradac, 2015), pp. 119-33. For the icons on Meteora and Cuenca, see: Fani Gargova, "The Meteora Icon of the Incredulity of Thomas Reconsidered," in Female Founders in Byzantium and Beyond, eds. Lioba Theis et al. (Vienna, 2014), pp. 369-81; Andrea Babuin, "Il dittico di Cuenca e l'Epiro in epoca tardo-medievale," in Byzantine Hagiography: Texts, Themes and Projects, ed. Antonio Rigo (Turnhout, 2018), pp. 419-49.

17 On the lost True Cross reliquary with a portrait of King Vladislav (r. 1234-1243) prostrate, originally in the Athonite monastery of Saint Paul, see: Arhimandrit Leonid, "Slovenosrpska knjižnica na Sv. Gori Atonskoj u manastiru Hilindaru i Sv. Pavlu," [Slavonic-serbian library on Holy Mount Athos in the monasteries Hilandar and St. Paul] Glasnik Srpskog učenog društva 44 (1877), 232-304, esp. 279-80.

18 For a comprehensive study of medieval Serbian coinage, see: Vujadin Ivanišević, Novčarstvo srednjovekovne Srbije [Coinage of medieval Serbia] (Belgrade, 2001). See also: Marjanović-Dušanić, Vladarske insignije, pp. 81-102 (with bibliography).

19 On the seals, see: Aleksa Ivić, Stari srpski pečati i grbovi. Prilog srpskoj sfragistici i heraldici [Old Serbian seals and coats of arms. Contribution to Serbian sfragistics and heraldry] (Novi Sad, 1910); Gregor Čremošnik, Studije za srednjovjekovnu diplomatiku i sigiliografiju Južnih Slavena [Studies in medieval diplomacy and sigiliography of the southern Slavs] (Sarajevo, 1976), pp. 43-148; Marjanović-Dušanić, Vladarske insignije, pp. 103-14. 
silver coins, issued by King Stefan Radoslav (r. 1228-1234) and minted using coin dies from the Empire of Thessalonica. Here, the reasoning behind this complete imitation was to articulate the close political alliance between the Serbian leadership and its southern neighbour, sealed by Radoslav's marriage to the daughter of Theodore Komnenos Doukas (r. 1215-1230). ${ }^{20}$ On his coins, Radoslav not only repurposed the numismatic iconography of the neighbouring Byzantine Greek state but also had his likeness labelled in Greek, pointing to his own identity as half Byzantine; he did the same when he signed his only known charter. ${ }^{21}$ That these imitations were far fetched is evident in the fact that on the coins he is shown holding a globus cruciger, an attribute that is rarely found on later Serbian coinage, never appears in monumental images of Serbian monarchs, and is not one of the Serbian royal insignia as attested by historical sources. ${ }^{22}$

One extreme case of western influence regards the Serbian aristocracy's usage of heraldic emblems. Their sudden appearance during the 14th century in fully developed forms on tombstone slabs, finger rings, coins, seals, and textiles can, according to recent research, be connected to contemporary Teutonic heraldry, since each one of them finds a parallel in the illustrated Zurich armorial, the oldest known of its type. ${ }^{23}$ It would appear that heraldry as a typically western custom entered Serbian society through the agency of the knight Palman, leader of the German mercenary court guards who served Stefan Uroš IV Dušan (r. 1331-1355), the Serbian king and later tsar, for more than 20 years in the mid-14th century. ${ }^{24}$

In this overview, I should briefly mention some instances of royal portraiture predating the founding of the Nemanjić dynasty. One example is in the castle chapel of Znojmo, as part of the famous Romanesque wall paintings dated to

20 Vujadin Ivanišević, "Novac kralja Radoslava," [Coinage of King Radoslav] Zbornik radova Vizantološkog instituta 37 (1998), 87-95; Ivanišević, Novčarstvo, pp. 87-79, 237-38, T. I (1.1-1.4).

21 On this ruler and his portraits, see: Branislav Cvetković, "Studenički eksonarteks i kralj Radoslav: prilog datovanju," [Studenica exonarthex and King Radoslav: a contribution to its dating] Zbornik radova Vizantološkog instituta 37 (1998), 75-85.

22 Smilja Marjanović-Dušanić, "The Ruler's Insignia in the Structural Evolution of Medieval Serbia," Majestas 7 (1999), 55-74, esp. 62.

23 On this armorial, see: Heinrich Runge, Die Wappenrolle von Zürich. Ein heraldisches Denkmal des vierzehnten Jahrhunderts (Zurich, 186o); Michel Popoff, Le rôle d'armes de Zurich (Paris, 2015).

24 For these discoveries, see: Vujadin Ivanišević, "Razvoj heraldike u srednjovekovnoj Srbiji," [Development of heraldry in medieval Serbia] Zbornik radova Vizantološkog instituta 41 (2004), 213-34. 
$1134{ }^{25}$ It displays Princess Maria, daughter of the Serbian grand župan Uroš I (r. 1112-1145) and wife of the Moravian prince Conrad II (r. 1112-1161), and belongs to the Central European tradition both in style and in the depicted insignia. ${ }^{26}$ Another pre-Nemanjić example of Serbian royal portraiture is that in the palatine chapel of Saint Michael the Archangel in Ston, Dalmatia (modern Croatia). This fresco shows a ruler wearing western attire and a western-type crown and holding a church-model. Whereas earlier scholarship identified the ruler as Mihailo, the first king of Doclea (r. c. 1050-1081), ${ }^{27}$ it has recently been argued that the portrait instead represents Stefan Vojislav (r. 1040-1043), the former's father and predecessor. ${ }^{28}$ In terms of insignia, the western-type crowns are often present on coinage and seals, and they reappear in monumental portraits in the Littoral region. ${ }^{29}$

It is important to highlight the rare joint portrayals of the Byzantine and Serbian rulers, like that found in the monastery church in Mileševa - the only example in which the Byzantine emperor was painted in a church on Serbian soil. It shows probably Alexios III Angelos on the south wall of the narthex facing King Stefan Nemanjić (known as 'the First-Crowned') and his two sons, who are depicted on the opposite north wall. ${ }^{30}$ Another example is in Chilandar

25 Kateřina Dvořáková, "Dating the Romanesque Mural Paintings and the Ducal Rotunda of St. Catherine, in Znojmo: New Discoveries," Interdisciplinaria Archaeologica. Natural Sciences in Archaeology 1/2 (2010), 99-104 (with bibliography).

26 On this portrait, see: Jovanka Kalić, “Kneginja Marija," [The princess Maria] Zograf 17 (1986), 21-35, figs. 1,7 .

27 Ivan Stevović, "O prvobitnom izgledu i vremenu gradnje crkve Sv. Mihajla u Stonu," [On the original appearance and construction date of the church of Saint Michael at Ston] Zbornik radova Vizantološkog instituta 35 (1996), 175-95; Tibor Živković, Portreti srpskih vladara: IX-XII vek [Portraits of Serbian rulers: $9^{\text {th }}$-12th centuries] (Belgrade, 2006), pp. 87-94. On a similar portrait most likely representing the Croatian king Petar Krešimir IV (r. 1059-1075), see: Igor Fisković, Reljef kralja Petra Krešimira IV. [The relief of King Petar Krešimir IV] (Split, 2002).

28 For the results of new research, see: Valentina Babić, Freske u crkvi Svetog Mihaila u Stonu [The frescoes of the church of Saint Michael at Ston] (Belgrade, 2014), pp. 159-82, T. 4849; Miodrag Marković, "Beginnings of artistic activity in the Serbian lands (9th-11th century)," in Sacral art, eds. Vojvodić and Popović, pp. 147-164, esp. 154-55, figs. 119, 120.

29 For one important example in Duljevo, see: Dragan Vojvodić, "Srpski vladarski portreti u manastiru Duljevu," [Portraits of Serbian rulers in the Duljevo monastery] Zograf 29 (2003), 143-6o.

30 On the identification, see: Božidar Ferjančić, and Ljubomir Maksimović, "Sveti Sava i Srbija između Epira i Nikeje," [Saint Sava and Serbia between Epiros and Nicaea] in Sveti Sava u srpskoj istoriji i tradiciji, [Saint Sava in Serbian history and tradition] ed. Sima Ćirković (Belgrade, 1998), pp. 13-25, esp. 21-24; Branislav Cvetković, "Vizantijski car i freske u priprati Mileševe," [Byzantine emperor and frescoes in Mileševa narthex] Balcanica 32-33 (2003), 297-309; Ljubomir Maksimović, “'Vizantinizmi' kralja Stefana Radoslava,” 
Monastery on Mount Athos and displays Emperor Andronikos II Paleologos delivering rolled charters to King Stefan Uroš II Milutin. ${ }^{31}$ What lay behind such portraiture were political alliances solidified through dynastic marriages. The written sources provide insight into the lost portrayals once installed in palaces and churches abroad, such as in Dubrovnik (modern Croatia), Buda (modern Hungary), and the monastery of Saint Paul on Mount Athos. ${ }^{32}$

\section{3} Holy Royals

The image-type most closely bound to the royal ideology of medieval Serbia is the genealogy in the form of a large tree. With its special character exemplified by a lineage of saintly rulers, the royal ideology stemmed from the organized worship of the dynasty founder, the grand župan Stefan Nemanja (r. 1166-1196; d. 1199), who later became an Athonite monk, taking the name Simeon. In 1207, his saintly relics were solemnly transferred from his original tomb at Chilandar Monastery on Mount Athos to the monastery church of Studenica (modern Serbia), which thus became the most important sacred site for the Serbian cult of saintly rulers. ${ }^{33}$ The significance of the transfer of

[The 'byzantinisms' of King Stefan Radoslav] Zbornik radova Vizantološkog instituta 46 (2009), 139-47, esp. 143-44.

31 Vojislav J. Đurić, "Les portraits de souverains dans le narthex de Chilandar," Hilandarski zbornik 7 (1989), 105-21; Dragan Vojvodić, "Ktitorski portreti i predstave," [Ktetors' portraits and representations] in Manastir Hilandar, [The monastery of Chilandar] ed. Gojko Subotić (Belgrade, 1998), pp. 249-57.

32 For these sources, see: Archimandrit Leonid, Athonskaya gora i Solovetskiy monastir [The Athonite Mountain and the Solovetskiy monastery] (St. Petersburg, 1883), p. 56; Radojčić, Portreti, p. 6o; Vojislav J. Đurić, Dubrovačka slikarska škola [Dubrovnik painting school] (Belgrade, 1963), p. 252; Jovanka Kalić, "Palata srpskih despota u Budimu," [Palace of Serbian despots in Buda] Zograf6 (1975), 51-58.

33 Đorđe Trifunović, Vera Bjelogrlić, and Irena Brajović, "Hilandarska povelja Svetoga Simeona i Svetoga Save," [Chilandari charter of Saint Simeon and Saint Sava] in Osam vekova Studenice, [Eight centuries of Studenica] ed. Stefan episkop žički (Belgrade, 1986), pp. 49-6o; Ljubomir Maksimović, "L'Idéologie du souverain dans l'État serbe et la construction de Studenica," in Studenica i vizantijska umetnost oko 1200. godine, [Studenica and Byzantine art c. 120o] ed. Vojislav Korać (Belgrade, 1988), pp. 33-49; Branislav Todić, "Ktitorska kompozicija u naosu Bogorodičine crkve u Studenici," [Ktetor's composition in the nave of the Virgin's church in Studenica] Saopštenja 29 (1997), 35-45; Gojko Subotić, Bojan Miljković, Irena Špadijer, and Ida Tot, Natpisi istorijske sadržine u zidnom slikarstvu. Tom prvi XII-XIV vek, [Inscriptiones historicae in picturis muralibus. Tomus primus saeculorum XII-XII] ed. Ljubomir Maksimović (Belgrade, 2015), pp. 35-44; Srđan Pirivatrić, "Hronologija i istorijski kontekst podizanja manastira Studenice. Prilog istraživanju problema," [The chronology and the historical context of the construction of the Studenica monastery. Contribution to the study] Zograf 39 (2015), 47-56; Miloš 
the relics of Saint Simeon is duly reflected in mural cycles based on his vita, which appear in special chapels adjacent to the katholika at Studenica and Sopoćani. ${ }^{34}$ The cult of Saint Simeon Nemanja gave rise to well-considered dynastic imagery intended to strengthen the legitimacy of his heirs, characterized by the prominent placement of the holy ancestor among his dynastic descendants. ${ }^{35}$

This imagery initially took a horizontally oriented form characteristic of all the other 13th-century examples of this iconographic type and gradually developed into colossal genealogies whose structure was based on the iconography of the Tree of Jesse. ${ }^{36}$ These images are magnificent not only in their monumentality but also in their formal variety and nuances of meaning. The earliest Serbian instance - a wall painting at Gračanica, dating to 1321 - was built upon notions of 'holy roots' and 'blessed shoots' carefully selected from Serbian hagiography and hymnography, with dynasty members interwoven in vines and petals. ${ }^{37}$ This example is distinctive in that its main message was connected to the unresolved succession of King Stefan Uroš II Milutin (r. 1282-1321); one of his sons, the future king Stefan Uroš III (later known as Stefan Dečanski), is absent from this genealogy because at the time he was expelled from the court. What is important to note here is that Saint Simeon is not depicted in his typical monastic habit but rather in imperial costume, an element that is multiplied vertically through all of his successors. A contrasting case is the Nemanjić family tree painted shortly after 1332 in the narthex of the patriarchate in Peć, one of the ancient seats of the Serbian ecclesiastical organization (Figure. 5.1). ${ }^{38} \mathrm{In}$

Živković, "Studenica: The Funerary Church of the Dynastic Founder - the Cornerstone of Church and State Independence," in Sacral art, eds. Vojvodić, and Popović, pp. 193-209.

34 See: Antony Eastmond, "'Local' Saints, Art, and Religious Iconography in the Orthodox World after the Fourth Crusade," Speculum 78/3 (2003), 707-17 (with bibliography).

35 For a structural analysis of Serbian royal images, see: Dragan Vojvodić, "Personalni sastav slike vlasti u doba Paleologa. Vizantija - Srbija - Bugarska," [The selection of royal figures in the image of power during the Palaiologan epoch: Byzantium - Serbia - Bulgaria] Zbornik radova Vizantološkog instituta 46 (2009), 409-33; Dragan Vojvodić, "Slika svetovne i duhovne vlasti u srpskoj srednjovekovnoj umetnosti," [The image of secular and spiritual authorities in Serbian medieval art] Zbornik za likovne umetnosti Matice srpske 38 (2010), 35-78.

36 For research devoted to different stages of the Nemanjić genealogical trees, see: Dragan Vojvodić, "Od horizontalne ka vertikalnoj genealoškoj slici Nemanjića," [From the horizontal to the vertical genealogical image of the Nemanjić dynasty] Zbornik radova Vizantološkog instituta 44/1 (2007), 295-312.

37 For a description of its full content, see: Branislav Todić, Gračanica. Slikarstvo [Gračanica. Wall paintings] (Belgrade, 1988), pp. 172-78, crt. XIX, T. Xx. See also: Branislav Todić, Serbian Medieval Painting: the Age of King Milutin (Belgrade, 1999).

38 Vojislav J. Đurić, Sima Ćirković, and Vojislav Korać, Pećka patrijaršija [The Patriarchate in Peć] (Belgrade, 1990), pp. 135-41, crt. XXv, sl. 82; Anđela Gavrilović, Crkva Bogorodice 
that it presents a larger number of dynasty members than its counterpart in Gračanica, this huge fresco reinforces the notion of the holiness of the ruling family as a whole. Its complex form can be explained not necessarily by the political context of the initial years of the reign of King Stefan Uroš IV Dušan, whose figure appears in the register of the composition just beneath Christ, but rather by the supervision of fresco programmes by Archbishop Danilo II himself, a highly learned, capable man and the instigator of the collection of vitas of the Serbian kings and archbishops. ${ }^{39}$

The best known among the five preserved Nemanjić family trees, the one in the monastery church at Dečani, painted in 1346/47, exemplifies yet another meaningful iteration of the image-type. Firstly, the fresco presents fewer full-length monarchs; they are surrounded by those from lateral branches of the dynasty, whose lesser importance is indicated by their representation en buste. Moreover, since the fresco was painted shortly after Dušan had been proclaimed tsar of the Serbs and Greeks, the main axis of the tree is visually underlined in accordance with the 'imperial line' of the Tree of Jesse, stressing the direct descendance of the new emperor from the most important agents of his dynasty, namely the holy founder (Saint Simeon Nemanja) and Milutin, Dušan's grandfather, who had also been canonized following his reign. ${ }^{40}$

The ideological notion of Nemanjić holy ancestry - a notion based on a perceived parallelism between the Serbian saintly dynasty and Christ's lineage, the Tree of Jesse - occasionally received more direct interpretations in art. In Dečani, for instance, the Tree of Jesse and the Nemanjić family tree share the same wall, depicted on either side south of the portal between the nave and the narthex. More prominently displayed juxtapositions of the two iconographies would follow. By the mid-14th century, not long after the mural was executed at Dečani, we find an unusual example painted on an exterior wall of the bell tower above the eastern gate at the monastery of Studenica. Two trees stand side by side, intertwined with one another. The colossal depiction must have originally been almost 15 metres high. Due to its damaged state, it was

Odigitrije u Pećkoj patrijaršiji [The church of the Virgin Odegetria in the Patriarchate in Peć] (Belgrade, 2018), passim.

39 On this extraordinary cleric, see: Arhiepiskop Danilo II i njegovo doba, [The archbishop Daniel II and his time] ed. Vojislav J. Đurić (Belgrade, 1991).

40 Branislav Todić, and Milka Čanak-Medić, Manastir Dečani [The monastery of Dečani] (Belgrade, 2005), pp. 444-47, sl. 365. See also: Dragan Vojvodić, "Portreti vladara, crkvenih dostojanstvenika i plemića u naosu i priprati," [Portraits of rulers, church dignitaries and patricians in nave and narthex] in Zidno slikarstvo manastira Dečana. Građa $i$ studije, [Mural painting of monastery of Dečani. Material and studies] ed. Vojislav J. Đurić (Beograd, 1995), pp. 265-99. 
first dated to the $15^{\text {th }}$ century ${ }^{41}$; however, after detailed analysis, it can arguably be re-dated to the reign of Tsar Stefan Dušan. ${ }^{42}$ Finally, the latest family tree within this corpus is found in the large monastery church of Mateič near Skopje, founded during the 135 os by Dušan's wife and son. Notwithstanding its poor condition, its structure reveals further novelties, most notably the inclusion of portraits of Byzantine and Bulgarian monarchs within the vines and flowers that run alongside the depicted members of the Nemanjić dynasty. Such a composite dynastic picture points to a redefining of the Serbian royals' self-concept as leaders of the 'new Israel', introducing aspects of the universalistic theories of Byzantine origin active in Serbian discourse at the time. ${ }^{43}$

It thus appears that various historical developments found more or less direct expression in the royal imagery of Serbia, a phenomenon that is worth comparing to the Bulgarian, ${ }^{44}$ Russian, ${ }^{45}$ Romanian, ${ }^{46}$ and Georgian material. ${ }^{47}$ Given that strife often unfolded among the closest relatives of the early Nemanjić ruling family, their official imagery sometimes displayed extremely detailed information on such grave circumstances as usurpation and fratricide. One distinctive case is found in the wall paintings of the socalled Deževo Chapel, adapted from the entrance tower to the monastery of Đurđevi Stupovi in Ras. Conceived to commemorate the state assembly held in 1282, at which King Stefan Dragutin (r. 1276-1282) had abdicated in favour of his younger brother, the chapel was painted in 1283 , such that almost all of its interior was covered with portraits and depictions of synods, coronations,

41 Vojislav J. Đurić, "Loza srpskih vladara u Studenici," [The lineage of Serbian rulers in Studenica] in Zbornik u čast Vojislava Đurića [Proceedings in honor of Vojislav Đurić] ed. Ivo Tartalja (Belgrade, 1992), pp. 67-79.

42 Dragan Vojvodić, "Rodoslovne predstave i ideja praroditeljstva u manastiru Studenici," [Genealogical representations and the idea of ancestry in the Studenica monastery] in Studenica monastery - 700 years of the King's Church, eds. Ljubomir Maksimović, and Vladimir Vukašinović (Belgrade, 2016), pp. 253-66.

43 Elizabeta Dimitrova, Manastir Matejče [The monastery of Matejče] (Skopje, 2002), pp. 214-21, sl. 86-87, T. LIV.

44 On the royal imagery of medieval Bulgaria, see: Georgi Atanasov, Insigniite na srednovekovnite b'lgarski vladeteli [The insignia of medieval Bulgarian rulers] (Pleven, 1999).

45 On medieval Russian royal images, see: Aleksander S. Preobrazhenskiy, Ktitorskiye portreti srednevekovoi Russi XI-nachalo XVI veka [Ktetors' portraits of medieval Russia 9th-beginning of 16th century] (Moscow, 2010).

46 On the portraiture of Wallachian and Moldavian rulers, see: Elisabeta Negrău, Cultul suveranului sud-est european și cazul Țării Românești: o perspectivă artistică [The cult of the southeast European sovereign and the case of the Romanian State: an artistic perspective] (Iași, 2011).

Antony Eastmond, Royal Imagery in Medieval Georgia (University Park Pennsylvania, 1998). 
and abdications. ${ }^{48}$ Likewise, segments of the wall decoration at Sopoćani bear witness to major ecclesiastical and political disputes of the period 1272-1274, when Michael viII Paleologos attempted to abolish the autocephalous status of both the Serbian and Bulgarian Churches. It is this context that lay behind the depiction of a Serbian state council among other ecumenical synods above the portrait of King Stefan Uroš I (r. 1243-1276) on the east wall of the narthex, whereby Uroš I defended the creed of the Serbian Orthodox Church and expressed his equal status to the Byzantine emperors. ${ }^{49}$ In the cathedral in Arilje, the fresco representing an imaginary state synod involving Saint Simeon Nemanja, who is shown in imperial costume rather than his monastic habit, seems not to address any particular event from history but to generally allude to a monarch's duties as defender of the true faith. ${ }^{50}$

Much more nuanced, however, is the representation of another fictional synod in the church of Saint Demetrius in Peć (Figure. 5.2). This unusually structured composition is found on one of the triangular segments in the rib vault of the west bay, as are the first and second ecumenical councils and that of Saint Sava the Serbian. Its long inscription explains the scene as the "Godassembled synod of Saint Simeon Nemanja and of his [great-] grandson the holy king Uroš II." The holy ancestor, dressed as a monk, points towards Uroš II, who is clad in the royal garb. The fresco aimed to promote the newly sainted king in the wake of the victory of his son Stefan Uroš III in the long civil war that had ensued after his death. The two national saints stand as the protectors of the fatherland, as Saint Demetrius was for Thessaloniki. That they are positioned under a ciborium in the painting probably reflects hymnographic references to both of them as 'the new myroblitai', on the model of Saint Demetrius, to whom the church was dedicated and whose shrine in Thessaloniki was characterized by a silver ciborium structure. ${ }^{51}$

48 Branislav Cvetković, "The Painted Programs in Thirteenth-Century Serbia: Structure, Themes, and Accents," in Orient et Occident méditerranéens au XIII siècle. Les programmes picturaux, eds. Jean-Pierre Caillet, and Fabienne Joubert (Paris, 2012), pp. 157-76, esp. 16870, figs. 14-15 (with bibliography).

49 Branislav Todić, "Apostol Andreja i srpski arhiepiskopi na freskama Sopoćana," [Apostle Andrew and Serbian archbishops on the frescoes of Sopoćani] in Papers of the Third Yugoslav Byzantine Studies Conference, eds. Ljubomir Maksimović, Ninoslava Radošević, and Ema Radulović (Belgrade, 2002), pp. 361-79, esp. 381-79.

$50 \quad$ Dragan Vojvodić, "Un regard nouveau sur la représentation du Concile de saint SiméonNemanja à Arilje," Cahiers balkaniques 31 (2000), 11-20; Dragan Vojvodić, Zidno slikarstvo crkve Svetog Ahilija u Arilju [Wall paintings of the church of Saint Achilleos in Arilje] (Belgrade, 2005), pp. 144-45, T. 3 o.

$5^{1}$ Branislav Cvetković, "Freske u zapadnom traveju crkve Sv. Dimitrija u Pećkoj patrijaršiji i kult kralja Milutina," [Frescoes from the western bay of Saint. Demetrius church in the 
Stefan Uroš II Milutin is well known in history for his complex personality and his seemingly contradictory orientation to Byzantium - on the one hand, having a longstanding bellicose attitude towards it and, on the other, completely accepting its court customs and artistic forms. He conquered large parts of Byzantium, laying a groundwork for the further spread of Serbia south of the Balkans during the reigns of his heirs; due to endowments he built and donated, he has since been worshipped as a saint in Serbia. ${ }^{52}$ Interestingly, his 'notoriety' is recorded by Dante in his Divine Comedy in a section enumerating several European rulers who, for various reasons, should end up in Hell. ${ }^{53}$ The episode is worth considering because the poet mentions a ruler of "Rascia" (i.e. Serbia) in the vague context of "not knowing well the Venetian mints." 54 In scholarship, this line has been understood as a direct allusion to King Milutin's ostensible counterfeiting of Venetian coinage..$^{55}$ The similarities between Venetian matapans and Serbian dinars are indeed striking, with the figure of the doge on the former being almost identical to that of the king on the latter. ${ }^{56}$ In some printed editions of Divine Comedy, the line mentioning the Serbian king is accompanied by a direct statement that the king made "false coins." 57 What actually took place was not a true forging of Venetian coinage but a serious monetary dispute between the two states resulting from a large export of Serbian silver dinars to the West. ${ }^{58}$

patriarchate of Peć and King Milutin's cult] Art Studies Quarterly 4 (200o), 3-9. On the ciborium in Thessaloniki, see: Laura Veneskey, "Truth and mimesis in Byzantium: a speaking reliquary of Saint Demetrios of Thessaloniki," Art history 42 (2019), 16-39 (with further bibliography).

$5^{2}$ On this ruler, see: Vlada Stanković, Kralj Milutin (1282-1321) [King Milutin (1282-1321)] (Belgrade, 2012) (with sources and bibliography).

53 For instance, see the manuscript Phillipps 9589, fol. 208v of Dante Alighieri's La Divina Commedia, copied in 1350 and now in the Biblioteca del Centro Dantesco in Ravenna.

54 For this mention of the Serbian ruler, see: Paget Toynbee, A Dictionary of Proper Names and Notable Matters in the Works of Dante (Oxford, 1898), pp. 42, 46o, 511, 554.

55 On these lines, see: Vittorio Russo, "Paradiso XIX 140-141: '... e quel di Rascia / che male ha visto (o male aggiustò) il conio di Vinegia,' " Studi danteschi 54 (1982), 99-111; Giuseppe Alonzo, "Numismatica dantesca. La Commedia tra maledizione e santificazione della moneta," in Stella forte: studi danteschi, ed. Francesco Spera (Napoli, 2010), pp. 81-106, esp. $92-93$.

56 David Metcalf, Coinage in South Eastern Europe, 820-1396 (London, 1979), p. 213; Alan M. Stahl, Zecca: The Mint of Venice in the Middle Ages (Baltimore, 200o), pp. 37-38, fig. 6; Susan Mosher Stuard, Gilding the Market: Luxury and Fashion in Fourteenth-Century Italy (Philadelphia, 2006), p. 155 .

57 On this comment on the margin, see: La Divina comedia di Dante, ed. Lodovico Dolce (Venice, 1555), pp. 512-13.

$5^{8}$ See: Ljubomir Nedeljković, "Mletačka intervencija protiv raškog dinara u XIII i XIV veku," [Venetian intervention against the dinar of Raska in the 13th and 14th centuries] Zbornik 
The conquest of Byzantine territories that had begun on a grand scale during the reign of King Milutin was continued by his grandson, King and Tsar Dušan. Backed by a strong economy, military power, and many allies, Dušan inserted himself significantly into the internal politics of Byzantium as well. His ambitions reached their apogee when he had himself proclaimed tsar, having successfully annexed the Greek mainland except for the Peloponnese. ${ }^{59}$ Official imagery duly echoed this rise from kingdom to tsardom, with the portrayals of Dušan gradually becoming larger and more solemn. However, this development is evident already in the magnificent wall paintings in Pološko, which were completed before Dušan became tsar. There, portraits of Dušan, his wife and son are placed above those of nobles on the east wall of the narthex. ${ }^{60}$ But the best known of his many portraits is undoubtedly the one on the north wall of the narthex in Lesnovo (Figure. 5.3), dating to 1349. The composition is colossal in size and far reaching in its ideological messages. Dušan's facial features are almost identical to those of Christ, and this Christomimesis is further highlighted by the Son of God's dispensing of crowns only to the lateral figures of the tsar's wife and son as well as by the overlapping of the top edge of Dušan's halo with the bottom edge of Christ's mandorla. ${ }^{61}$ Among the insignia, the crown, sceptre, the sakkos, and even the suppedion adorned with bicephalous eagles had all been in use since the mid-13th century. More novel though deriving from antiquity and appearing also in the earlier 14th-century programmes at Peć and Pološko - is the loros cloth crossed at the chest. This style of wearing the loros marks the Serbian rulers as the direct successors of Constantine, ${ }^{62}$ one of the key tenets of royal ideology of the time. ${ }^{63}$

Narodnog muzeja 6 (1970), 287-308; Ivanišević, Novčarstvo, pp. 39-41; Srđan Šarkić, "Stefan Uroš Milutin - 'Sveti kralj' ili stanovnik Danteovog 'Pakla,' " [Stefan Uros Milutin The 'Holy King' or a resident of Dante's Hell] Zbornik radova Pravnog fakulteta 37/1-2 (2003), 59-63.

59 On the rise of Serbia to tsardom, see: Smilja Marjanović-Dušanić, and Dragan Vojvodić, "The Model of Empire - the Idea and Image of Authority in Serbia (1299-1371)," in Sacral Art, eds. Vojvodić, and Popović, pp. 299-315 (with bibliography).

6o On these portraits, see: Ivan M. Đorđević, Zidno slikarstvo srpske vlastele u doba Nemanjića [The wall-paintings of the Serbian nobility of the Nemanide era] (Belgrade, 1994), pp. 119, 147-49, crt. 37 .

61 On the portraits in Lesnovo, see: Smiljka Gabelić, Manastir Lesnovo. Istorija i slikarstvo [The monastery of Lesnovo. History and painting] (Belgrade, 1998), pp. 167-69, sl. 78, T. XL-XLII.

62 For an important discussion on this matter, see: Dragan Vojvodić, "Ukrštena dijadima i 'torakion.' Dve drevne i neuobičajene insignije srpskih vladara u XIV i XV veku," [The crossed diadem and 'thorakion.' Two ancient and unusual insignia of Serbian rulers in the 14th and 15th centuries] in Papers, eds. Maksimović et al., pp. 249-76.

63 For the seminal study, see: Vojislav J. Đurić, "Le nouveau Constantin dans l'art serbe

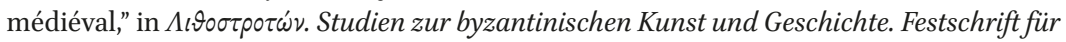


As noted above, the Nemanjić rulers had first drawn inspiration from the Byzantine aristocracy, before looking to the model of Byzantine imperial art. $^{64}$ The earliest known representation of a Nemanjić, preserved only in traces, was superbly executed in $1208 / 9$ by one of the greatest artists of Constantinople, who was commissioned to decorate the katholikon of the monastery of Studenica. The portrait of the grand župan Stefan, originally part of a complex fresco programme for the monastery's eastern gate, displays him wearing a mantle and crowned with a wreath, probably a sign of his title of sebastokrator, which he had received upon his marriage to the daughter of Alexios III Angelos. ${ }^{65}$ Some other vestiges of the early Nemanjić portraits have been recent objects of research. One group of portrayals is found in a small room on the third floor of the entrance tower to the monastery church in Žiča, the first seat of the Serbian autocephalous archbishopric. There, the surfaces of the groin vault feature partially damaged fulllength portraits of male members of the royal family, painted in the $1220{ }^{6}{ }^{66}$ In addition, flanking the main entrance to the tower are portraits of King Stefan the First-Crowned and his eldest son, King Stefan Radoslav. Originally executed in the third decade of the 13th century, these two figures were repainted around 1309, during the refurbishment of Žiča under King Stefan Uroš II Milutin. ${ }^{67}$

Marcel Restle, eds. Thomas Steppan, and Birgitt Borkopp (Stuttgart, 20oo), pp. 55-65. Cf. New Constantines. The Rhythm of Imperial Renewal in Byzantium, 4th-13th centuries, ed. Paul Magdalino (Aldershot, 1994).

64 For recent research with new documentation, see: Dragan Vojvodić, "Ka carskom dostojanstvu kraljevske vlasti: vladarske insignije i ideologija u doba prvih Nemanjića," [Towards the imperial dignity of royal rulership: insignia and ideology under the first Nemanjić rulers] in Kraljevstvo i arhiepiskopija u srpskim i pomorskim zemljama Nemanjića, [The kingdom and the archbishopric of the Serbian and maritime lands of the Nemanjić dynasty] eds. Ljubomir Maksimović, and Srđan Pirivatrić (Belgrade, 2019), pp. 315-54.

65 On all the frescoes of the gate, see: Bojan Miljković, "Slikarstvo zapadnog ulaza u manastiru Studenici iz 1208/9. godine," [The painting of the western entrance of the monastery of Studenica from the year 1208/9] in Papers, ed. Maksimović et al., pp. 183-88.

66 For a recent study of these enigmatic portraits, see: Milka Čanak-Medić, Danica Popović, and Dragan Vojvodić, Manastir Žiča [The monastery of Žiča] (Belgrade, 2014), pp. 319-38, sl. 220-25.

67 For comprehensive research on these portraits, see: Dragan Vojvodić, "Portreti prvih ktitora u prizemlju žičke kule. Poreklo ikonografije," [Portraits of the first donors on the 
But among the early Nemanjić portraits, the most interesting are those in the narthex of the monastery church of Mileševa (from 1220s). The lavish gallery includes depictions of Saint Simeon Nemanja and his son Archbishop Sava the Serbian, as spiritual leaders of the royal family, followed by King Stefan the First-Crowned and two of his sons, Stefan Radoslav and Stefan Vladislav, the latter depicted in the role of ktetor (founder) and thus holding a church-model. The remnants of the inscriptions have given rise to discussions on the meaning of the complex composition as well as its dating. ${ }^{6}$ The portraits convey the figures' preeminent and foundational status with respect to state and ecclesiastical matters: Prince Vladislav is the ktetor of the monastery; his older brother is the firstborn son and successor to King Stefan the First-Crowned; and Sava is the first archbishop of the Serbian Church. The inscription beside the figure of Saint Simeon Nemanja most likely designated him as "the first renovator of the Serbian fatherland," as he was referred to in the chapter headings of his vita. ${ }^{69}$ Such a label is obviously based on the notion of Christ's primacy as the firstborn of the New Testament yet also a fulfilment of the Old Testament narrative of Israel as the chosen people. There are two chapters in Domentijan's vita of Saint Simeon Nemanja that clearly emphasize the primacy of Saint Simeon as the firstborn by divine choice. There, Domentijan compares him not only with several Old Testament characters but also with Christ himself, the New Adam, with syntagmas derived from Saint Paul's Epistle to the Colossians (Col.1:15-18) as the

ground floor of the Žiča tower. Origin of the iconography] Niš \& Byzantium 10 (2012), 323-39.

68 Đorđe Trifunović, "Natpisi uz portrete Nemanjića u manastiru Mileševi," [Inscriptions with portraits of Nemanjić in the Mileševa monastery] Književnost i jezik 2-4 (1992), 91-100, esp. 94-95; Vojislav J. Đurić, "Srpska dinastija i Vizantija na freskama u manastiru Mileševi," [The Serbian dynasty and Byzantium on frescoes in the Mileševa monastery] Zograf 22 (1992), 13-25; Branislav Todić, "Novo tumačenje programa i rasporeda fresaka u Mileševi," [A new interpretation of the program and layout of murals in Mileševa] in Na tragovima Vojislava J. Đurića, [On the trail of Vojislav J. Đurić] eds. Dejan Medaković, and Cvetan Grozdanov (Belgrade, 2011), pp. 55-68; Gojko Subotić, and Ljubomir Maksimović, "Sveti Sava i podizanje Mileševe," [Saint Sava and the construction of Mileševa] in Vizantijski svet na Balkanu 1, [Byzantine world in the Balkans] eds. Bojana Krsmanović, Ljubomir Maksimović, and Radivoj Radić (Belgrade, 2012), pp. 97-106.

69 For detailed studies on this matter, see: Branislav Cvetković, "Sveti Sava i program živopisa u Mileševi: prilozi istraživanju," [Saint Sava and paintings in Mileševa: addenda to research] in Osam vekova manastira Mileševe 1, [Eight centuries of Mileševa monastery] ed. Petar Vlahović (Mileševa, 2013), pp. 311-27; Branislav Cvetković, "St Constantine the Great in Mileševa Revisited," Niš \& Byzantium 12 (2014), 271-84. 
firstborn of all creation and the firstborn from the dead. All these terms are directly echoed in the headlines in Saint Simeon Nemanja's vita as well as in the iconography and inscriptions of the narthex in Mileševa. This chapter in Domentijan's vita, overlooked in earlier scholarship, moreover offers crucial evidence about the ideology espoused by Nemanja and his heirs in that it introduces Jacob's blessing of his sons, an Old Testament narrative emphasizing the divine elect of royalty. ${ }^{70}$

The portraits in Mileševa contain further precious information regarding insignia and royal costume. The king and his two sons are dressed in sticharia and mantles, while only the king and his older son and heir wear thin wreaths on their heads. The question of insignia was crucial for Stefan the First-Crowned, given that it was actually the papacy that crowned him king, in $1217 .^{71}$ Due to careful research on the traces in the Mileševa narthex, which points to subsequent modifications having been made to all the royal figures, it is now possible to conclude that, probably during the 1230 s, crowns in the form of stemma (dome-shaped crown) with falling prependoulia were added to the portraits of Stefan, Radoslav, and Vladislav. Whether the additions were executed simultaneously for all the figures is an open question ${ }^{72}$; due to slight yet discernible differences it may be surmised that the insertion of the crown was made to Stefan and Radoslav first, and only later to Vladislav. ${ }^{73}$ These modifications point to major changes in royal ideology, which may have resulted from the Bulgarians' defeat of the Byzantine Greeks (Empire of Thessalonica) in the Battle of Klokotnitsa, in 123o. This was the context for the addition of the dome-shaped crown to the Mileševa portrait of Prince Vladislav (Figure. 5.4), who was married to the daughter of the Bulgarian tsar and became the king of Serbia following the deposition of his Grecophile older brother Radoslav in the early 1230 . This event was recorded in the fresco with the insertion not only of the crown but also of a large inscription announcing Vladislav as king. ${ }^{74}$ The portrait of Vladislav in Mileševa, with the added crown clearly visible, is thus one piece of data vividly illustrating the complexity of medieval Balkan politics.

70 For notions of Jacob and his blessing as important to the ideology of the Nemanjić dynasty, see: Marjanović-Dušanić, Vladarska ideologija Nemanjića, pp. 191-97 (with sources and bibliography).

71 Vojvodić, "Ka carskom," pp. 318-37.

72 Vojvodić, "Ka carskom," pp. 341-51 (with bibliography).

73 Đurić, "Srpska dinastija," pp. 17-23, sl. 9-10.

74 Đurić, "Srpska dinastija," pp. 20-21, sl. 7. 
There are of course many more examples of Serbian imagery illustrating historical twists and turns, including portraits of usurpers and aspirants to power. It goes without saying that such instances are often not firmly corroborated by written sources. However, tectonic shifts following major battles can shed light on the motives behind some of these works. One such case is that of the monastery church of Nova Pavlica, endowed by the two brothers of the Mussic family, Stefan and Lazar, who are depicted there as ktetors and sole representatives of power. Their portrayal as supreme wielders of power can be explained by their position as nephews of the Serbian ruler Stefan Lazar, who was killed in the Battle of Kosovo in 1389; it seems that after the demise of their uncle, the family had no one else to pay allegiance to. ${ }^{75}$ One finds a similar situation in the portraits of rulers and dignitaries in the monastery church in Velucee, a number of which are unidentifiable due to a lack of inscriptions and other historical data, despite a number of attempts to identify them and to date the erection and decoration of the church (with hypotheses ranging from the mid14 th to mid-15th centuries). One can argue that this unusual ensemble reflects the outcome of the civil war waged in the first decade of the 15th century between Stefan and Vuk of the Lazarević dynasty, which resulted in a temporary division of the state. ${ }^{76}$

The urge to accentuate one's own legitimacy was always at the core of royal imagery. One astounding example is found in the church of Saint Demetrius in Peć, whose rib-vault decoration, containing depictions of both historical and symbolic synods, was mentioned above (Figure. 5.2). Within the larger fresco programme, which belongs to the first years of the rule of King Stefan Uroš III following his exile from court, the portraits on the south wall of the west bay are especially ideologically charged (Figure. 5.5). They testify to the immediate aftermath of the civil war between the three pretenders to the throne, including Stefan Uroš III upon his return from exile in Constantinople. The specificity of the historical circumstances explains why the composition finds no iconographic parallel, neither earlier nor later. The portraits are set against a

75 For a detailed discussion of these portraits, see: Branislav Cvetković, "Portreti u naosu Nove Pavlice: istorizam ili politička aktuelnost?, [Portraits in the naos of Nova Pavlica: historicism or current politics?] Saopštenja 35/36 (2006), 79-97; Branislav Cvetković, and Gordana Gavrić, Manastir Nova Pavlica [The monastery of Nova Pavlica] (Brvenik, 2014), pp. $26-27,36-39$.

76 Branislav Cvetković, and Gordana Gavrić, Manastir Veluće [The monastery of Veluće] (Kraljevo, 2015), pp. 21-44 (with bibliography). 
dark-red background. On the left stands Nikodim, the ktetor of the church and acting archbishop at the time. On the opposite end is Saint Sava the Serbian, the founder of the Serbian Orthodox Church and himself a member of the first generation of the Nemanjić dynasty. Between the two church prelates stand the newly crowned king and his young son Dušan, the future king and tsar. ${ }^{77}$ Their costumes are unusual, obviously reflecting their years spent in the Byzantine capital. ${ }^{78}$ With his long sleeves hanging unbelted, the young prince wears a style called the granatza, fashionable at the time in Byzantium and the Balkans and described by Pseudo-Kodinos in his treatise on dignitaries as being of Assyrian origin. ${ }^{79} \mathrm{An}$ important comparable example of how imagery served in promoting royal children is found in the cathedral in Arilje. Although the ktetor of the church, King Stefan Dragutin, had already abdicated by the time this decorative programme was executed, his two sons were given prominent placement beneath the Tree of Jesse in the narthex to highlight his lineage's continued claim to the Serbian throne. Moreover, his older son, Prince Vladislav, is singled out by the overlapping of the top of his aureole with the bottom of Christ's mandorla. ${ }^{80}$

The issue of producing a male heir was among the most crucial for royals in the Middle Ages. The lack of a legitimate heir could pave the way to crisis and almost always led to civil war. Such a situation accounts for the content of the frescoes commissioned in Peć and elsewhere during the final years of the reign of King Stefan Uroš II Milutin. Despite his numerous marriages, he died without an apparent heir, such that the issue of his succession had to be resolved through a bloody war between his two sons and a nephew, each of whom lacked proper legitimacy. ${ }^{81}$ But the king had indeed tried to produce an heir

77 For a complete study addressing these issues, see: Branislav Todić, "Srpske teme na freskama XIV veka u crkvi sv. Dimitrija u Peći," [Serbian themes in 14th-century frescoes in the church of Saint Demetrios in Peć] Zograf 30 (2004-05), 123-40 (with bibliography).

78 See: Maria G. Parani, "Cultural Identity and Dress: The Case of Late Byzantine Ceremonial Costume," Jahrbuch der Österreichischen Byzantinistik 57 (2007), 95-134.

79 When the sleeves were belted at the back, as was common among Byzantine courtiers, the style was called the lapatzas. The third variant, ordered for the megas domestikos, with one sleeve falling loose and the other belted, reflected the special place John Kantakouzenos held at the court of Andronikos III. See: Branislav Cvetković, "Prilog proučavanju vizantijskog dvorskog kostima - $\gamma p \alpha \nu \alpha \dot{\alpha} \zeta \alpha, \lambda \alpha \pi \dot{\alpha} \tau \zeta \alpha \varsigma$," [A contribution to the

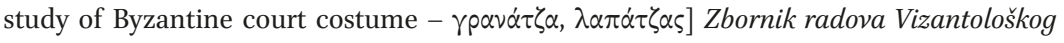
instituta 34 (1995), 143-55.

8o Branislav Cvetković, "Christianity and Royalty: The Touch of the Holy," Byzantion $72 / 2$ (2002), 347-64, esp. 354-57, fig. 4.

81 Vlada Stanković, "King Milutin and his Many Marriages (*1254, †November 21, 1321, r. 1282-1321)," in Portraits of Medieval Eastern Europe, 900-1400, eds. Donald G. Ostrowski, and Christian Raffensperger (London, 2018), pp. 109-19. 
whose right to inherit the throne could not be challenged. His fifth marriage to Simonis, the daughter of the Byzantine emperor Andronikos II Paleologos was a means to accomplish even wider ambitions, reaching towards the unification of Serbia with the Kingdom of Thessalonica, ruled by Empress Eirene (Yolanda of Montferrat), the wife of Andronikos. The infertility of the young bride prevented such grand plans, and it seems that the king sought help from above by commissioning the building of a special chapel in the renowned dynastic mausoleum of Studenica. ${ }^{82}$ The so-called King's Church is dedicated to Saint Anne and Saint Joachim, the parents of the Virgin. Its unusual decoration, with images of the ktetors and the holy doctors, makes it an extraordinary example of the belief in the saints as channels of God's healing power. The busts of Saint Cosmas and Saint Damian are painted not in their usual frontal postures but rather almost bent towards the royal couple. Partly damaged, Saint Damian turns towards Queen Simonis, pointing at her with his instrument. Saint Cosmas, too, is shown in profile, with his right arm outstretched towards the king, likewise pointing directly to him with the sharp end of his scalpel (Figure. 5.6).$^{83}$ The royal couple is depicted alongside the patron saints on the south wall. The king holds a church-model, while Saint Anne holds the young Virgin. By showing the two couples side by side, the painters stressed the parallel between the main theme of the illustrated cycle of the Virgin's infancy (sterility healed) and the desired outcome for the Serbian royal couple. The childless couple dedicates the lavish foundation to Saint Anne and Saint Joachim, whose sterility was miraculously cured by divine mercy. ${ }^{84}$

The far-reaching consequences of barren dynastic marriages gave rise to even more captivating royal imagery, for example in the monastery church in Psača. Two frontal figures are shown dressed in the typical sakkos and loros (Figure. 5.7). The younger of the pair is Emperor Stefan Uroš v, the son of

82 For detailed analysis of the issues, see: Branislav Cvetković, "König Milutin und die Parakklesiai des Hl. Joachim und der Hl. Anna im Kloster Studenica," Balcanica 26 (1995), $2^{25}-76$. For results of research on this monument, see: Gordana Babić, Kraljeva crkva $u$ Studenici [The King's Church in Studenica] (Belgrade, 1987).

83 Branislav Cvetković, "Intentional Asymmetry in Byzantine Imagery: The Communion of the Apostles in St Sophia in Ohrid and Later Instances," Byzantion 76 (2006), 74-96, esp. $87-88$.

84 Branislav Cvetković, "The icon in context: Its functional adaptability in medieval Serbia," in Saints of the Balkans, eds. Mirjana Detelić, and Graham Jones (Donington, 2006), pp. 42-5o, esp. 46; Eirini Panou, "Mary's parents in the Byzantine art of Eastern Europe and the Balkans," in Proceedings of the 2nd International symposium Days of Justinian I, ed. Mitko B. Panov (Skopje, 2015), pp. 193-95. Also, for the crucial role of Saint Anne in fertility beliefs at the Byzantine court, see: Eirini Panou, The Cult of St Anna in Byzantium (London - New York, 2018), pp. 20, 49-78. 
Dušan, while the grey-haired man is King Vukašin, presented as co-ruler. ${ }^{85}$ This fresco dates from the period when, due to his lacking an heir, Emperor Uroš was compelled to introduce as co-ruler the leading member of the mighty Mrnjavčević clan. But the wall painting actually provides further information in that the portrait of Vukašin was applied on a new fresco layer, over the figure of a nun likely standing for the mother of the emperor. The remnants of this female figure are still discernible at the joints between the different fresco layers. ${ }^{86}$

Elsewhere in the region, other politically motivated revisions to monumental programmes can be found. For instance, large areas of the nave of Sopoćani were repainted to accommodate an image of the deposition of King Stefan Uroš I, even including instances of a damnatio memoriae. ${ }^{87}$ In Dečani too, repainting is evident in several figures in the nave, necessitated by the political situation of the time. ${ }^{88}$ Some such instances are difficult to comprehend in their current condition, for instance at Gračanica, where modifications to the decorative programme are discernible only in pale outlines of the two royal figures between the portraits of the king's parents. ${ }^{89}$

\section{Lineage and Triumph}

After the death in 1371 of both Emperor Stefan Uroš v and his co-ruler, King Vukašin, the latter fallen in the Battle of Maritsa, the Serbian Empire disintegrated into more or less independent units ruled by regional overlords, some of whom were legitimate heirs of the old Nemanjić dynasty. ${ }^{90}$ This was the case

85 Đorđević, Zidno slikarstvo, pp. 172-73, T. 26-27, sl. 77 (with bibliography).

86 See: Zagorka Rasolkoska-Nikolovska, "O istorijskim portretima u Psači i vremenu njihovog nastanka," [About historical portraits in Psača and the time of their creation] Zograf 24 (1995), 39-51; Zagorka Rasolkoska-Nikolovska, "Istoriskite portreti vo Psača i vremeto na nivnoto slikanje," [Historical portraits in Psača and the time of their painting] in Srednovekovnata umetnost vo Makedonija. Freski i ikoni, [Medieval art in Macedonia. Frescoes and icons] ed. Darko Nikolovski (Skopje, 2004), pp. 245-65.

87 For a thorough analysis, see: Branislav Todić, "Sopoćani i Gradac. Uzajamnost funerarnih programa dve crkve," [Sopoćani and Gradac. About the relation of funerary programmes of the two churches] Zograf 31 (2006-07), 59-76.

88 Todić, and Čanak-Medić, Manastir Dečani, pp. 436-46, sl. 358, (with bibliography).

89 Dragan Vojvodić, "Doslikani vladarski portreti u Gračanici," [Additionally painted portraits of rulers in Gračanica] Niš \& Byzantium 7 (2009), 251-65.

90 Branislav Cvetković, "In Search of Legitimacy: The Ideology and Art of the New Serbian Dynasts," in Sacral Art, eds. Vojvodić, and Popović, pp. 411-21. Also, for arts of the period, see: Tatjana Starodubcev, Srpsko zidno slikarstvo u zemljama Lazarevića i Brankovića 
with King Marko, who with his brothers and close allies reigned over the southern parts of the dissolved Empire and who expressed his royal aura in several dazzling portraits. ${ }^{91}$ The northern regions of medieval Serbia likewise came to be governed by former local nobles who gradually rose to supreme power, from Lazar Hrebeljanović and Vuk Branković to Stefan Lazarević and Đurađ Branković. Although they would base their official portraiture on imagery from previous decades and from the traditions of the Nemanjić dynasty, these powerful figures also made numerous adaptations - whether to titles, insignia, or costume - and, due to their often precarious positions as rulers, seem to have constructed their images of authority using nuanced iconographic models. ${ }^{92}$ After decades of crisis, it was the despot Stefan Lazarević (r. 1389-1427) who managed to solidify his authority, especially after the favourable outcome of the Battle of Angora in 1402 and his decisive victories over the Ottomans and various domestic enemies up to 1412 . His portrayals in several monastery churches conveyed particularly complex messages. In Koporin, he is depicted alone in a purple sakkos with a loros crossed over his breast. By contrast, in Rudenice, he is shown as a donor among the ktetor-aristocrats, standing next to his co-ruler and brother, Vuk, and all the figures are dressed in luxury court attire with long mantles (Figure. 5.8). The situation is similar in Kalenić and Sisojevac, where the despot also features as one of the ktetors. ${ }^{93}$ That he is shown wearing a mantle in these images is an important piece of evidence

1-2 [Serbian wall painting in the lands of the Lazarević and Branković families] (Belgrade, 2016).

91 Cvetković, "Intentional Assymetry," pp. 90-92, fig. 7; Branislav Cvetković, "Sovereign Portraits at Mark's Monastery Revisited," IKON 5 (2012), 185-98; Marka Tomić Đurić, "New Kingdom in the South - Art in the Mrnjavčević State," in Sacral Art, eds. Vojvodić, and Popović, pp. 367-79; Marka Tomić Đurić, Freske Markovog manastira [The frescoes of Marko's monastery] (Belgrade, 2019), pp. $45^{-1} 78$ (with full bibliography).

92 For various instances, see: Branislav Cvetković, "Ideološki modeli i motivi u vladarskoj reprezentaciji despota Stefana," [Ideological models and motives in royal representations of despot Stefan Lazarević] in Srednji vek u srpskoj nauci, istoriji, književnosti i umetnosti 7, [The Middle Ages in Serbian science, history, literature and art] ed. Gordana Jovanović (Despotovac, 2016), pp. 57-78.

93 On these issues, see: Branislav Cvetković, "Manastir Sisojevac i monah Sisoje," [The monastery of Sisojevac and the monk Sisoes] Istorija umetnosti 1-2 (2002), 55-76; Branislav Cvetković, “Rudenice i Kalenić: 'dvojna,' grupna ili sukcesivna ktitorija?," [Rudenice and Kalenić: 'dual,' group or successive khtêtoria?] Saopštenja 41 (2009), 79-98; Branislav Cvetković, "Kalenić: ikonografija i politička teorija," [Kalenić: iconography and political theory] in Manastir Kalenić. U susret šestoj stogodišnjici, [Monastery Kalenić. On the eve of the six hundred years anniversary] ed. Jovanka Kalić (Belgrade, 2009), pp. 47-65; Branislav Cvetković, "The Portraits in Lapušnja and Iconography of Joint Ktetorship," Niš \& Byzantium 11 (2013), 295-307. 
regarding the influence of Byzantium in later medieval Serbia, since this garb the chlamys of meekness - was reserved to stress the virtue of a pious ruler in Byzantine and Serbian royal portraits. For instance, it appeared in images accentuating the specific relationship between the representatives of the earthly and heavenly courts, but not in images speaking just to the heavenly origin of a sovereign's authority. ${ }^{94}$ Even in the most spiritual donations, however, the allure of temporal power often prevailed, which is why the family portrait of Despot Đurađ Branković (r. 1427-1456) on the Esphigmenou charter from 1429 , despite the visual placement of the family in front of the celestial lodgings of the Heavenly Jerusalem, is otherwise extremely luxurious. ${ }^{95}$

Finally, representations of medieval rulers often sought to emphasize military triumph and prowess. ${ }^{96}$ It has recently been argued that weapons in portraits of Byzantine and Balkan monarchs should not be interpreted as a sign of any particular military success, due to the fact that swords and spears are often mentioned among the insignia of crowning ceremonies. ${ }^{97}$ However, one wonders then why such arms are so seldomly a feature of official portraiture. ${ }^{98}$ That the inclusion of the sword as an attribute indeed signalled actual military success is evidenced in the monastery church of Staro Nagoričino (Figure. 5.9). The fresco was executed in the year of King Milutin's great victories over several units of the Turks both in the Balkans and in aid of Andronikos II Paleologos in Asia Minor. The king is depicted as renovator of the old Byzantine foundation, with Saint George handing him the sword - the symbol of the victory achieved with the help of this holy warrior and megalomartyr - in exchange

94 On mantles, see: Branislav Cvetković, "Plašt srpskih despota u 15. veku. Prilog proučavanju," [The mantle of the Serbian despots in the 15th century. A contribution to the study] in Vizantijski svet na Balkanu 2, [Byzantine world in the Balkans] eds. Bojana Krsmanović, Ljubomir Maksimović, and Radivoj Radić (Belgrade, 2012), pp. 551-61.

95 Branislav Cvetković, "Esfigmenska povelja despota Đurđa Brankovića: fantastična arhitektura, Žiča, Esfigmen ili nebeski stanovi?," [The Esphigmenou Chrysobull of Despot Đurađ Branković: Fantastic Architecture, Žiča, Esphigmenou or the Celestial Dwellings?] in IYMMEIKTA, ed. Ivan Stevović (Belgrade, 2012), pp. 343-63.

96 Michael McCormick, Eternal Victory: Triumphal Rulership in Late Antiquity, Byzantium and the Early Medieval West (Cambridge, 1990).

97 Dragan Vojvodić, "Oružje s nebesa. Ikonologija srednjovekovnih predstava investiture vladara vojnim insignijama," [Weapons from heavens. Iconology of medieval representations of the investiture of rulers by military insignia] in Pristupna predavanja dopisnih članova 1, [Access lectures by correspondent members] ed. Miro Vuksanović (Belgrade, 2019), pp. 237-58.

98 On this important issue, see: Robert S. Nelson, "And So, With the Help of God. The Byzantine Art of War in the Tenth Century," Dumbarton Oaks Papers 65/66 (2011/12), $169-92$. 
for the restored church. ${ }^{99}$ The victory would also have been recorded in a modification to the founder's inscription on the stone lintel of the western door of the church.

A rare example of the iconography of the Serbian monarch being invested with weapons from the heavens is the magnificent portrait of Despot Stefan Lazarević at his burial site, the monastery church of Resava (Figure. 5.10). He holds in his right hand a cruciform sceptre and, in his left, a model of the church and an unfurled scroll bearing a prayer to the monastery's patron, the Holy Trinity. He is clad in a rich sakkos, patterned with medallions containing bicephalous eagles, over which the bands of the loros are visible; wearing red shoes, he stands on the suppedion embroidered with two lions en passant. ${ }^{100}$ From the celestial register above, Christ crowns and blesses him, while an angel on either side invests him with a sword and a spear, respectively. A crucial chapter from the despot's biography, describing the importance of his military victories, ${ }^{101}$ may explain the iconography of this triumphant portrayal. ${ }^{102}$

Workshops

This survey of the royal imagery of medieval Serbia has brought into focus the programmatic and iconographic features of a number of portraits. However, also of interest are the origins of the painters as well as the style of these works of art. As far as the royally endowed churches are concerned, the majority were painted by the leading workshops of the major Byzantine cultural centres,

99 Vojislav J. Đurić, “Tri događaja u srpskoj državi XIV veka i njihov odjek u slikarstvu,” [Three events in a 14th-century Serbian state and their echo in painting] Zbornik za likovne umetnosti Matice srpske 4 (1966), 68-76, crt. 1, sl. 1; Branislav Todić, Staro Nagoričino (Belgrade, 1993), pp. 118-19, crt. 21.

100 Jadranka Prolović, Resava (Manasija). Geschichte, Architektur und Malerei einer Stiftung des serbischen Despoten Stefan Lazarević (Vienna, 2017), pp. 347-56, where the author gives several erratic and unacceptable descriptions of Christ as an angel and of the lions on the suppedion as a snake and a lion, thus arguing that the royal cushion symbolizes evil.

101 Vatroslav Jagić, "Konstantin Filosof i njegov Život Stefana Lazarevića despota srpskoga," [Constantine the Philosopher and his life of Stefan Lazarević the Serbian despot] Glasnik Srpskog učenog društva 42 (1875), 223-328, esp. 281.

102 Branislav Cvetković, "Imago leonis in despot Stefan's Iconography," IKON 2 (2009), 13745; Branislav Cvetković, "Portret despota Stefana u Resavi: istoriografija i ikonografija," [Despot Stefan's portrait in Resava: historiography and iconography] in Srednji vek u srpskoj nauci, istoriji, književnosti i umetnosti 11, [The Middle Ages in Serbian science, history, literature and art] ed. Gordana Jovanović (Despotovac, 2021), pp. 219-54. 
Constantinople and Thessaloniki. The most stylistically refined painter of the early 13th century in this region was responsible for the decoration of the katholikon of the monastery of Studenica. Although he left his signature in the dome, the name of this artist remains unknown due to the damaged condition of this inscription. ${ }^{103}$ Despite a lack of signatures, the high artistic value of the frescoes painted in the 1220 s in the katholikon in Žiča corroborates the information provided in the vita of Saint Sava the Serbian that the best metropolitan painters were summoned to decorate this church, the first seat of the autocephalous Serbian archbishopric. ${ }^{104}$ On the basis of style and other characteristics, it has long been ascertained that the wall paintings in the katholikon of the monastery of Mileševa were executed by leading artists who most likely came to Serbia from Thessaloniki. ${ }^{105}$ This second city of the Byzantine Empire was also the point of origin for an extremely productive workshop headed by the Astrapas family. The two leaders of this atelier, the painters Eutychios and Michael, were probably father and son. In addition to their signed work in several churches, their distinctive style has allowed scholars to attribute to them the decoration of the main foundations of King Milutin. ${ }^{106}$ An equally prominent group of painters originating in Thessaloniki was undoubtedly responsible for many of the frescoes at the later royal endowments in Ravanica, Sisojevac, and Resava. ${ }^{107}$

103 Vojislav J. Đurić, "La plus ancienne peinture de Studenica à la lumière de l'historiographie," in Studenica i vizantijska umetnost oko 1200. godine, [Studenica and Byzantine art circa 120o] ed. Vojislav Korać (Belgrade, 1988), pp. 171-84.

104 Čanak-Medić et al., Manastir Žiča, pp. 347-391 (with bibliography).

105 Vojislav J. Đurić, "Mileševsko najstarije slikarstvo. Izvori i paralele," [Mileševa's oldest painting. Sources and Parallels] in Mileševa u istoriji srpskog naroda, [Mileševa in the history of the Serbian people] ed. Vojislav J. Đurić (Belgrade, 1987), pp. 27-35 (with bibliography).

106 Miodrag Marković, "Umetnička delatnost Mihaila i Evtihija. Sadašnja znanja, sporna pitanja i pravci budućih istraživanja," [Michael's and Eutychios's artistic work. Present knowledge, dubious issues and direction of future research] Zbornik Narodnog muzeja 17 / 2 (2004), 95-117; Miodrag Marković, "The painter Eutychios - father of Michael Astrapas and protomaster of the frescoes in the Church of the Virgin Peribleptos in Ohrid," Zbornik za likovne umetnosti Matice srpske 38 (2010), 9-34.

107 Vojislav J. Đurić, "Istoriografsko-memoarska beleška o umetničkom poreklu resavskih slikara," [A historical-memoir note on the artistic origins of the Resava painters] in Manastir Resava. Istorija i umetnost, [Resava Monastery. Its history and art] ed. Vojislav J. Đurić (Despotovac, 1995), pp. 25-36; Tatjana Starodubcev, "Slikari zadužbina Lazarevića," [Painters of the Endowments of the Lazarević dynasty] Zbornik radova Vizantološkog instituta 43 (2006), 349-91. 
As this essay has shown, the sheer quantity of preserved material from Serbia brings to the fore a variegated and extremely nuanced sampling of the content of medieval royal portraiture. The very fact that this imagery is mostly found in the medium of fresco on church walls in villages, towns, and monasteries whereas there is only little evidence of comparable examples in miniatures and icons - bespeaks its importance as a propaganda tool. The audience for these images was wide, considering firstly their religious contexts and the fact that the founding of churches was a conduit not only to personal but also collective redemption and, secondly, their cultic elements, modelled after a Western European royal ideology of holy ancestors. ${ }^{108}$ Although they were set within churches, the function of royal portraits was deeply political due to the old and essential belief in the divine origin of the power of worldly rulers. ${ }^{109} \mathrm{In}$ the case of medieval Serbia, such imagery was tasked with evoking key notions of the springing of power from holy dynastic ancestors, notions elaborated in hagiographic texts devoted to various members of the sanctified Nemanjić family. ${ }^{110}$ The most telling sources for understanding the place of royal imagery in medieval Serbian society are genealogies and chronicles, similar to the short Byzantine annals. While the royal genealogies were conceived to corroborate the legitimacy of a given dynastic branch and, therefore, emerged during moments of political disturbance, the chronicles covered more complex issues and identified the most important political players of the time. ${ }^{111}$ Although the former were written at the royal court and the latter within monastic circles, all these texts abound with historically specific messages and, thus, are precious sources for construing the nuances encountered in the royal imagery.

108 Joan A. Holladay, Visualizing Ancestry in the High and Late Middle Ages (Cambridge, 2019).

109 See: Ivan Drpić, "Review of R. Franses, Donor portraits in Byzantine art: the vicissitudes of contact between human and divine," Church history 88/3 (2019), 806-808.

110 Smilja Marjanović-Dušanić, "La réécriture hagiographique: usages et fonctions dans la Serbie médiévale," in Remanier, métaphraser. Fonctions et techniques de la réécriture dans le monde byzantin, eds. Smilja Marjanović- Dušanić, and Bernard Flusin (Belgrade, 2011), pp. 163-8o; Smilja Marjanović-Dušanić, "Svod srpskih svetih u doba kralja Milutina: dinastički kultovi," [The 'pantheon' of Serbian saints during King Milutin's reign: the dynastic cults] in Studenica monastery - 7oo years of the King's Church, eds. Ljubomir Maksimović, and Vladimir Vukašinović (Belgrade, 2016), pp. 35-59.

111 Marija Vasiljević, "Nastanak srpskih rodoslova i letopisa kao posledica političkih i društvenih promena," [The emergence of Serbian genealogies and chronicles as a consequence of political and social changes] Initial. A review of medieval studies 3 (2015), 95-117; Marija Vasiljević, "Imagining the ruler's genealogy in medieval Serbia," Revue des études sud-est européennes 55 (2017), 73-88. 


\section{Bibliography}

\section{Primary Sources}

Alighieri, Dante, La Divina Commedia, Ms Phillipps $95^{89}$ (1350), Biblioteca del Centro Dantesco, Ravenna.

Ivić, Aleksa, Stari srpski pečati i grbovi. Prilog srpskoj sfragistici i heraldici [Old Serbian seals and coats of arms. Contribution to Serbian sfragistics and heraldry] (Novi Sad, 1910).

Jagić, Vatroslav, "Konstantin Filosof i njegov Život Stefana Lazarevića despota srpskoga," [Constantine the Philosopher and his life of Stefan Lazarević the Serbian despot] Glasnik Srpskog učenog društva 42 (1875), 223-328.

La Divina comedia di Dante, ed. Lodovico Dolce (Venice, 1555).

Leonid, Arhimandrit, "Sloveno-srpska knjižnica na Sv. Gori Atonskoj u manastiru Hilindaru i Sv. Pavlu," [Slavonic-serbian library on Holy Mount Athos in the monasteries Hilandar and St. Paul] Glasnik Srpskog učenog društva 44 (1877), 232-304.

Popoff, Michel, Le rôle d'armes de Zurich (Paris, 2015).

Runge, Heinrich, Die Wappenrolle von Zürich. Ein heraldisches Denkmal des vierzehnten Jahrhunderts (Zurich, 186o).

Trifunović, Đorđe, Bjelogrlić, Vera, and Brajović, Irena, "Hilandarska povelja Svetoga Simeona i Svetoga Save," [Chilandari charter of Saint Simeon and Saint Sava] in Osam vekova Studenice, [Eight centuries of Studenica] eds. Stefan episkop žički (Belgrade, 1986), pp. 49-6o.

\section{Secondary Sources}

Alonzo, Giuseppe, "Numismatica dantesca. La Commedia tra maledizione e santificazione della moneta," in Stella forte: studi danteschi, ed. Francesco Spera (Napoli, 2010), pp. 81-106.

Arhiepiskop Danilo II i njegovo doba, [The archbishop Daniel II and his time] ed. Vojislav J. Đurić (Belgrade, 1991).

Atanasov, Georgi, Insigniite na srednovekovnite b'lgarskivladeteli [The insignia of medieval Bulgarian rulers] (Pleven, 1999).

Babić, Gordana, Kraljeva crkva u Studenici [The King's Church in Studenica] (Belgrade, 1987).

Babić, Gordana, "Western Medieval and Byzantine Traditions in Serbian Art," in Tradition and Modern Society, ed. Sven Gustavsson (Stockholm, 1989), pp. 117-32.

Babić, Valentina, Freske u crkvi Svetog Mihaila u Stonu [The frescoes of the church of Saint Michael at Ston] (Belgrade, 2014).

Babuin, Andrea, "Il dittico di Cuenca e l'Epiro in epoca tardo-medievale," in Byzantine Hagiography: Texts, Themes and Projects, ed. Antonio Rigo (Turnhout, 2018), pp. 419-49.

Ball, Jeniffer L., Byzantine Dress. Representations of Secular Dress in Eighth- to TwelfthCentury Painting (New York, 2005). 
Blagojević, Miloš, Srbija u doba Nemanjića [Serbia in the Nemanjić era] (Belgrade, 1989).

Bogdanović, Dimitrije, Istorija stare srpske književnosti [History of old Serbian literature] (Belgrade, 1980).

Bogdanović, Dimitrije, "Politička filosofija srednjovekovne Srbije. Mogućnosti jednog istraživanja," [Political philosophy of medieval Serbia. Possibilities of research] Filosofske studije 16 (1984), 7-28.

Bojović, Boško, L'Idéologie monarchique dans les hagio-biographies dynastiques du Moyen Âge serbe (Roma, 1995).

Bubalo, Đorđe, Srpska zemlja i pomorska u doba vladavine Nemanjića 1 [Serbian lands and the Littoral during the Nemanjić reign] (Belgrade, 2016).

Čanak-Medić, Milka, Popović, Danica, and Vojvodić, Dragan, Manastir Žiča [The monastery of Žiča] (Belgrade, 2014).

Ćirković, Sima, The Serbs (Malden, 2004).

Čremošnik, Gregor, Studije za srednjovjekovnu diplomatiku i sigiliografiju Južnih Slavena [Studies in medieval diplomacy and sigiliography of the southern Slavs] (Sarajevo, 1976).

Cvetković, Branislav, "König Milutin und die Parakklesiai des Hl. Joachim und der Hl. Anna im Kloster Studenica," Balcanica 26 (1995), 251-76.

Cvetković, Branislav, "Prilog proučavanju vizantijskog dvorskog kostima - $\gamma \rho \alpha \nu \alpha \dot{\tau \zeta} \alpha$, $\lambda \alpha \pi \dot{\alpha} \tau \zeta \alpha \varsigma$, , [A contribution to the study of Byzantine court costume - $\gamma \rho \alpha \nu \alpha \dot{\tau} \zeta \alpha$, $\lambda \alpha \pi \dot{\alpha} \tau \zeta \alpha \varsigma]$ Zbornik radova Vizantološkog instituta 34 (1995), 143-55.

Cvetković, Branislav, "Studenički eksonarteks i kralj Radoslav: prilog datovanju," [Studenica exonarthex and King Radoslav: a contribution to its dating] Zbornik radova Vizantološkog instituta 37 (1998), 75-85.

Cvetković, Branislav, "Freske u zapadnom traveju crkve Sv. Dimitrija u Pećkoj patrijaršiji i kult kralja Milutina," [Frescoes from the western bay of Saint Demetrius church in the patriarchate of Peć and King Milutin's cult] Art Studies Quarterly 4 (2000), 3-9.

Cvetković, Branislav, "Christianity and Royalty: The Touch of the Holy," Byzantion 72/ 2 (2002), 347-64.

Cvetković, Branislav, "Manastir Sisojevac i monah Sisoje," [The monastery of Sisojevac and the monk Sisoes] Istorija umetnosti 1-2 (2002), 55-76.

Cvetković, Branislav, "Vizantijski car i freske u priprati Mileševe," [Byzantine emperor and frescoes in Mileševa narthex] Balcanica 32-33 (2003), 297-309.

Cvetković, Branislav, "The icon in context: Its functional adaptability in medieval Serbia," in Saints of the Balkans, ed. Mirjana Detelić, and Graham Jones (Donington, 2006), pp. 42-50.

Cvetković, Branislav, "Intentional Asymmetry in Byzantine Imagery: The Communion of the Apostles in St Sophia in Ohrid and Later Instances," Byzantion 76 (2006), $74-96$. 
Cvetković, Branislav, “Portreti u naosu Nove Pavlice: istorizam ili politička aktuelnost?, [Portraits in the naos of Nova Pavlica: historicism or current politics?] Saopštenja 35/36 (2006), pp. 79-97.

Cvetković, Branislav, "Imago leonis in despot Stefan's Iconography," IKON 2 (2009), 137-45.

Cvetković, Branislav, "Kalenić: ikonografija i politička teorija," [Kalenić: iconography and political theory] in Manastir Kalenić. U susret šestoj stogodišnjici, [Monastery Kalenić. On the eve of the six hundred years anniversary] ed. Jovanka Kalić (Belgrade, 2009), pp. 47-65.

Cvetković, Branislav, “Rudenice i Kalenić: 'dvojna,' grupna ili sukcesivna ktitorija?,” [Rudenice and Kalenić: 'dual,' group or successive khtêtoria?] Saopštenja 41 (2009), $79-98$.

Cvetković, Branislav, "Robes of Light and the 13th Century Frescoes in Boyana," in The Boyana Church Between the East and the West in the Art of the Christian Europe, ed. Bisserka Penkova (Sofia, 2011), pp. 198-214.

Cvetković, Branislav, "Esfigmenska povelja despota Đurđa Brankovića: fantastična arhitektura, Žiča, Esfigmen ili nebeski stanovi?," [The Esphigmenou Chrysobull of Despot Đurađ Branković: Fantastic Architecture, Žiča, Esphigmenou or the Celestial Dwellings?] in IYMMEIKTA, ed. Ivan Stevović (Belgrade, 2012), pp. 343-63.

Cvetković, Branislav, "Sovereign Portraits at Mark's Monastery Revisited," IKON 5 (2012), 185-98.

Cvetković, Branislav, "Plašt srpskih despota u 15. veku. Prilog proučavanju," [The mantle

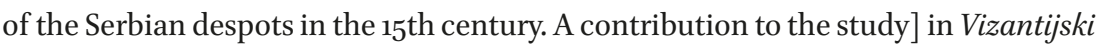
svet na Balkanu 2, [Byzantine world in the Balkans] eds. Bojana Krsmanović, Ljubomir Maksimović, and Radivoj Radić (Belgrade, 2012), pp. 551-61.

Cvetković, Branislav, "Sovereign Portraits at Mark's Monastery Revisited," IKON 5 (2012), 185-98.

Cvetković, Branislav, "The Painted Programs in Thirteenth-Century Serbia: Structure, Themes, and Accents," in Orient et Occident méditerranéens au XIII siècle. Les programmes picturaux, eds. Jean-Pierre Caillet, and Fabienne Joubert (Paris, 2012), pp. $157-76$.

Cvetković, Branislav, "The Portraits in Lapušnja and Iconography of Joint Ktetorship," Niš \& Byzantium 11 (2013), 295-307.

Cvetković, Branislav, "Sveti Sava i program živopisa u Mileševi: prilozi istraživanju," [Saint Sava and paintings in Mileševa: addenda to research] in Osam vekova manastira Mileševe 1, [Eight centuries of Mileševa monastery] eds. Petar Vlahović (Mileševa, 2013), pp. 311-27.

Cvetković, Branislav, "Medieval Serbian Art between Byzantium and West," in Art and Its Role in the History: Between Durability and Transient-Isms, ed. Branko Jovanović et al. (Kosovska Mitrovica, 2014), pp. 311-28. 
Cvetković, Branislav, "St Constantine the Great in Mileševa Revisited," Niš \& Byzantium 12 (2014), 271-84.

Cvetković, Branislav, and Gavrić, Gordana, Manastir Nova Pavlica [The monastery of Nova Pavlica] (Brvenik, 2014).

Cvetković, Branislav, and Gavrić, Gordana, "Kraljica Jelena i franjevci," [Queen Helen and the franciscans] in Jelena - kraljica, monahinja, svetiteljka, [Helen - the queen, the nun, the saint] ed. Katarina Mitrović (Gradac, 2015), pp. 119-33.

Cvetković, Branislav, and Gavrić, Gordana, Manastir Veluće [The monastery of Veluće] (Kraljevo, 2015).

Cvetković, Branislav, “Textiles and Their Usage in Medieval Balkans: The Royal Context,” in Clothing the Sacred. Medieval Textiles as Fabric, Form, and Metaphor, eds. Mateusz Kapustka, and Warren T. Woodfin (Berlin, 2015), pp. 33-52.

Cvetković, Branislav, "Ideološki modeli i motivi u vladarskoj reprezentaciji despota Stefana," [Ideological models and motives in royal representations of despot Stefan Lazarević] in Srednji vek u srpskoj nauci, istoriji, književnosti i umetnosti 7, [The Middle Ages in Serbian science, history, literature and art] ed. Gordana Jovanović (Despotovac, 2016), pp. 57-78.

Cvetković, Branislav, "In Search of Legitimacy: The Ideology and Art of the New Serbian Dynasts," in Sacral Art of the Serbian Lands in the Middle Ages, eds. Dragan Vojvodić, and Danica Popović (Belgrade, 2016), pp. 411-21.

Cvetković, Branislav, "Portret despota Stefana u Resavi: istoriografija i ikonografija," [Despot Stefan's portrait in Resava: historiography and iconography] in Srednji vek u srpskoj nauci, istoriji, književnosti i umetnosti 11, [The Middle Ages in Serbian science, history, literature and art] ed. Gordana Jovanović (Despotovac, 2021), pp. 219-54.

Dagron, Gilbert, Empereur et prêtre. Étude sur le 'césaropapisme' byzantin (Paris, 1996).

Dimitrova, Elizabeta, Manastir Matejče [The monastery of Matejče] (Skopje, 2002).

Đorđević, Ivan M., Zidno slikarstvo srpske vlastele u doba Nemanjića [The wall-paintings of the Serbian nobility of the Nnemanide era] (Belgrade, 1994).

Drpić, Ivan, "Review of R. Franses, Donor portraits in Byzantine art: the vicissitudes of contact between human and divine," Church history 88/3 (2019), 8o6-8o8.

Đurić, Vojislav J., Dubrovačka slikarska škola [Dubrovnik painting school] (Belgrade, 1963).

Đurić, Vojislav J., "Tri događaja u srpskoj državi XIV veka i njihov odjek u slikarstvu," [Three events in a 14th-century Serbian state and their echo in painting] Zbornik za likovne umetnosti Matice srpske 4 (1966), 68-76.

Đurić, Vojislav J., "Slika i istorija u srednjovekovnoj Srbiji," [Image and history in medieval Serbia] Glas Srpske akademije nauka i umetnosti 338 (1983), 117-33. 
Đurić, Vojislav J., "Mileševsko najstarije slikarstvo. Izvori i paralele," [Mileševa's oldest painting. Sources and Parallels] in Mileševa u istoriji srpskog naroda, [Mileševa in the history of the Serbian people] ed. Vojislav J. Đurić (Belgrade, 1987), pp. 27-35.

Đurić, Vojislav J., "La plus ancienne peinture de Studenica à la lumière de l'historiographie," in Studenica i vizantijska umetnost oko 1200. godine, [Studenica and Byzantine art circa 1200] ed. Vojislav Korać (Belgrade, 1988), pp. 171-84.

Đurić, Vojislav J., "Les portraits de souverains dans le narthex de Chilandar," Hilandarski zbornik 7 (1989), 105-21.

Đurić, Vojislav J., "Društvo, država i vladar u umetnosti u doba dinastije LazarevićBranković," [Society, state and ruler in art during the Lazarević-Branković dynasty] Zbornik za likovne umetnosti Matice srpske 26 (1990), 13-41.

Đurić, Vojislav J., "Loza srpskih vladara u Studenici," [The lineage of Serbian rulers in Studenica] in Zbornik u čast Vojislava Đurića [Proceedings in honor of Vojislav Đurić] ed. Ivo Tartalja (Belgrade, 1992), pp. 67-79.

Đurić, Vojislav J., "Srpska dinastija i Vizantija na freskama u manastiru Mileševi," [The Serbian dynasty and Byzantium on frescoes in the Mileševa monastery] Zograf 22 (1992), 13-25.

Đurić, Vojislav J., "Istoriografsko-memoarska beleška o umetničkom poreklu resavskih slikara," [A historical-memoir note on the artistic origins of the Resava painters] in Manastir Resava. Istorija i umetnost, [Resava Monastery. Its history and art] ed. Vojislav J. Đurić (Despotovac, 1995), pp. 25-36.

Đurić, Vojislav J., "Le nouveau Constantin dans l'art serbe médiéval," in $\Lambda \imath$ $\vartheta \tau \tau \rho \tau \tau \dot{\nu} v$. Studien zur byzantinischen Kunst und Geschichte. Festschrift für Marcel Restle, eds. Thomas Steppan, and Birgitt Borkopp (Stuttgart, 200o), pp. 55-65.

Đurić, Vojislav J., Ćirković, Sima, and Korać, Vojislav, Pećka patrijaršija [The Patriarchate in Peć] (Belgrade, 1990).

Dvořáková, Kateřina, "Dating the Romanesque Mural Paintings and the Ducal Rotunda of St. Catherine, in Znojmo: New Discoveries," Interdisciplinaria Archaeologica. Natural Sciences in Archaeology 1/2 (2010), 99-104.

Eastmond, Antony, Royal Imagery in Medieval Georgia (University Park Pennsylvania, 1998).

Eastmond, Antony, "Local' Saints, Art, and Religious Iconography in the Orthodox World after the Fourth Crusade," Speculum 78/3 (2003), 707-17.

Ferjančić, Božidar, and Maksimović, Ljubomir, "Sveti Sava i Srbija između Epira i Nikeje," [Saint Sava and Serbia between Epiros and Nicaea] in Sveti Sava u srpskoj istoriji i tradiciji, [Saint Sava in Serbian history and tradition] ed. Sima Ćirković (Belgrade, 1998), pp. 13-25.

Fisković, Igor, Reljef kralja Petra Krešimira IV. [The relief of King Petar Krešimir IV] (Split, 2002). 
Franses, Rico, Donor Portraits in Byzantine Art: The Vicissitudes of Contact between Human and Divine (New York, 2018).

Gabelić, Smiljka, Manastir Lesnovo. Istorija i slikarstvo [The monastery of Lesnovo. History and painting] (Belgrade, 1998).

Gargova, Fani, "The Meteora Icon of the Incredulity of Thomas Reconsidered," in Female Founders in Byzantium and Beyond, eds. Lioba Theis, Margaret Mullet, Michael Grünbart, Galina Fingarova, and Matthew Savage (Vienna, 2014), pp. 369-81.

Gavrilović, Anđela, Crkva Bogorodice Odigitrije u Pećkoj patrijaršiji [The church of the Virgin Odegetria in the Patriarchate in Peć] (Belgrade, 2018).

Grabar, André, L'empereur dans l'art byzantin. Recherche sur l'art officiel de l'empire d'orient (Paris, 1936).

Holladay, Joan A., Visualizing Ancestry in the High and Late Middle Ages (Cambridge, 2019).

Istorija srpskog naroda 1 [History of the Serbian nation], ed. Sima Ćirković (Belgrade, 1981).

Istorija srpskog naroda 2 [History of the Serbian nation], ed. Jovanka Kalić (Belgrade, 1982).

Ivanišević, Vujadin, "Novac kralja Radoslava," [Coinage of King Radoslav] Zbornik radova Vizantološkog instituta 37 (1998), 87-95.

Ivanišević, Vujadin, Novčarstvo srednjovekovne Srbije [Coinage of medieval Serbia] (Belgrade, 2001).

Ivanišević, Vujadin, "Razvoj heraldike u srednjovekovnoj Srbiji," [Development of heraldry in medieval Serbia] Zbornik radova Vizantološkog instituta 41 (2004), 213-34.

Kalić, Jovanka, "Palata srpskih despota u Budimu," [Palace of Serbian despots in Buda] Zograf 6 (1975), 51-58.

Kalić, Jovanka, "Kneginja Marija," [The princess Maria] Zograf 17 (1986), 21-35.

Kalić, Jovanka, Srbi u poznom srednjem veku [Serbs in the Late Middle Ages] (Belgrade, 1994).

Kašanin, Milan, Srpska književnost u srednjem veku [Serbian literature in the Middle Ages] (Belgrade, 1975).

Klaniczay, Gábor, Holy Rulers and Blessed Princesses. Dynastic Cults in Medieval Central Europe (Cambridge, Eng. 2002).

Kovačević, Jovan, Srednjovekovna nošnja balkanskih Slovena. Studija iz istorije srednjovekovne kulture Balkana [Medieval costume of the Balkan Slavs. A study in history of the medieval culture of the Balkans] (Belgrade, 1953).

Krsmanović, Bojana, and Maksimović, Ljubomir, "Byzantium in Serbia - Serbian Authenticity and Byzantine Influence," in Sacral Art of the Serbian Lands in the Middle Ages, eds. Dragan Vojvodić, and Danica Popović (Belgrade, 2016), pp. 41-56.

Leonid, Archimandrit, Athonskaya gora i Solovetskiy monastir [The Athonite Mountain and the Solovetskiy monastery] (St. Petersburg, 1883). 
Maksimović, Ljubomir, "L'Idéologie du souverain dans l'État serbe et la construction de Studenica," in Studenica i vizantijska umetnost oko 1200. godine, [Studenica and Byzantine art c. 1200] ed. Vojislav Korać (Belgrade, 1988), pp. 33-49.

Maksimović, Ljubomir, “'Vizantinizmi' kralja Stefana Radoslava,” [The 'byzantinisms' of King Stefan Radoslav] Zbornik radova Vizantološkog instituta 46 (2009), 139-47.

Marjanović-Dušanić, Smilja, Vladarske insignije i državna simbolika u Srbiji od XIII do $X V v e k a$ [The rulers' insignia and the state symbolism of medieval Serbia] (Belgrade, 1994).

Marjanović-Dušanić, Smilja, Vladarska ideologija Nemanjića. Diplomatička studija [Royal ideology of the Nemanjić. A diplomatic study] (Belgrade, 1997).

Marjanović-Dušanić, Smilja, "The Ruler's Insignia in the Structural Evolution of Medieval Serbia," Majestas 7 (1999), 55-74.

Marjanović-Dušanić, Smilja, Sveti kralj. Kult Stefana Dečanskog [The holy king. The cult of St. Stefan of Dečani] (Belgrade, 2007).

Marjanović-Dušanić, Smilja, "La réécriture hagiographique: usages et fonctions dans la Serbie médiévale," in Remanier, métaphraser. Fonctions et techniques de la réécriture dans le monde byzantin, eds. Smilja Marjanović- Dušanić, and Bernard Flusin (Belgrade, 2011), pp. 163-80.

Marjanović-Dušanić, Smilja, "La mort et la sainteté du prince serbe," in La mort du prince de l'Antiquité à nos jours, eds. Jérémie Foa, Élizabeth Malamut, and Charles Zaremba (Aix-en-Provence, 2016), pp. 61-78.

Marjanović-Dušanić, Smilja, "Svod srpskih svetih u doba kralja Milutina: dinastički kultovi," [The 'pantheon' of Serbian saints during King Milutin's reign: the dynastic cults] in Studenica monastery - 7oo years of the King's -Church, eds. Ljubomir Maksimović, and Vladimir Vukašinović (Belgrade, 2016), pp. 35-59.

Marjanović-Dušanić, Smilja, and Vojvodić, Dragan, "The Model of Empire - the Idea and Image of Authority in Serbia (1299-1371)," in Sacral Art of the Serbian Lands in the Middle Ages, eds. Dragan Vojvodić, and Danica Popović (Belgrade, 2016), pp. 299-315.

Marković, Miodrag, “Umetnička delatnost Mihaila i Evtihija. Sadašnja znanja, sporna pitanja i pravci budućih istraživanja," [Michael's and Eutychios's artistic work. Present knowledge, dubious issues and direction of future research] Zbornik Narodnog muzeja 17/2 (2004), 95-117.

Marković, Miodrag, "The painter Eutychios - father of Michael Astrapas and protomaster of the frescoes in the Church of the Virgin Peribleptos in Ohrid," Zbornik za likovne umetnosti Matice srpske 38 (2010), 9-34.

Marković, Miodrag, "Beginnings of artistic activity in the Serbian lands (9th-11th century)," in Sacral Art of the Serbian Lands in the Middle Ages, eds. Dragan Vojvodić, and Danica Popović (Belgrade, 2016), pp. 147-64.

McCormick, Michael, Eternal Victory: Triumphal Rulership in Late Antiquity, Byzantium and the Early Medieval West (Cambridge, 1990). 
Metcalf, David, Coinage in South Eastern Europe, 820-1396 (London, 1979).

Miljković, Bojan, "Slikarstvo zapadnog ulaza u manastiru Studenici iz 1208/9. godine," [The painting of the western entrance of the monastery of Studenica from the year 1208/9] in Papers of the Third Yugoslav Byzantine Studies Conference, eds. Ljubomir Maksimović, Ninoslava Radošević, and Ema Radulović (Belgrade, 2002), pp. $183-88$.

Miljković, Bojan, "Nemanjići i Sveti Nikola u Bariju," [The Nemanjić and Saint Nicholas in Bari] Zbornik radova Vizantološkog instituta 44/1 (2007), 275-94.

Nedeljković, Ljubomir, "Mletačka intervencija protiv raškog dinara u XIII i XIV veku," [Venetian intervention against the dinar of Raska in the 13th and 14th centuries] Zbornik Narodnog muzeja 6 (1970), 287-308.

Negrău, Elisabeta, Cultul suveranului sud-est european și cazul Țării Românești: o perspectivă artistică [The cult of the southeast European sovereign and the case of the Romanian State: an artistic perspective] (Iași, 2011).

Nelson, Robert S., "And So, With the Help of God. The Byzantine Art of War in the Tenth Century," Dumbarton Oaks Papers 65/66 (2011/12) 169-92.

New Constantines. The Rhythm of Imperial Renewal in Byzantium, 4th-13th Centuries, ed. Paul Magdalino (Aldershot, 1994).

Panou, Eirini, "Mary's parents in the Byzantine art of Eastern Europe and the Balkans," in Proceedings of the 2nd International symposium Days of Justinian I, ed. Mitko B. Panov (Skopje, 2015), pp. 188-99.

Panou, Eirini, The Cult of St Anna in Byzantium (London - New York, 2018).

Parani, Maria G., Reconstructing the Reality of Images. Byzantine Material Culture and Religious Iconography (11th-15th centuries) (Leiden, 2003).

Parani, Maria G., "Cultural Identity and Dress: The Case of Late Byzantine Ceremonial Costume," Jahrbuch der Österreichischen Byzantinistik 57 (2007), 95-134.

Pirivatrić, Srđan, "Hronologija I istorijski kontekst podizanja manastira Studenice. Prilog istraživanju problema," [The chronology and the historical context of the construction of the Studenica monastery. Contribution rpske study] Zograf 39 (2015), 47-56.

Podskalsky, Gerhard, Theologische Literatur des Mittelalters in Bulgarien und Serbien 865-1459 (Munich, 2000).

Popović, Bojan, Srpska srednjovekovna vladarska i vlasteoska odeća [Serbian Medieval Royal and Nobility Costume] (Belgrade, 2020).

Popović, Danica, Srpski vladarski grob u srednjem veku [The royal tomb in medieval Serbia] (Belgrade, 1992).

Popović, Danica, "Predstava vladara nad 'carskim vratima' crkve Svetih arhanđela kod Prizrena," [Representation of sovereigns above 'imperial doors' of the church of Saint Archangels near Prizren] Saopštenja 26 (1994), 25-36. 
Popović, Danica, Pod okriljem svetosti. Kult svetih vladara i relikvija u srednjovekovnoj Srbiji [Under the auspices of sanctity. The cult of holy rulers and relics in medieval Serbia] (Belgrade, 2006).

Popović, Danica, Riznica spasenja. Kult relikvija I srpskih svetih u srednjovekovnoj Srbiji [The treasury of salvation. The cult of relics and the Serbian saints in medieval Serbia] (Belgrade, 2018).

Popović, Bojan, and Cvetković, Branislav, "Odevanje i kićenje," [Costume and adornment] in Privatni život u srpskim zemljama srednjeg veka, [Daily life in the Serbian lands of the middle ages] eds. Smilja Marjanović-Dušanić, and Danica Popović (Belgrade, 2004), pp. 367-93.

Preobrazhenskiy, Aleksander S., Ktitorskiye portreti srednevekovoi Russi XI-nachalo $X V I$ veka [Ktetors' portraits of medieval Russia 9th-beginning of 16th century] (Moscow, 2010).

Prolović, Jadranka, Resava (Manasija). Geschichte, Architektur und Malerei einer Stiftung des serbischen Despoten Stefan Lazarević (Vienna, 2017).

Radojčić, Svetozar, Portreti srpskih vladara u srednjem veku [Portraits of Serbian rulers in the Middle Ages] (Skopje, 1934).

Rasolkoska-Nikolovska, Zagorka, "O istorijskim portretima u Psači i vremenu njihovog nastanka," [About historical portraits in Psača and the time of their creation] Zograf 24 (1995), 39-51.

Rasolkoska-Nikolovska, Zagorka, "Istoriskite portreti vo Psača i vremeto na nivnoto slikanje," [Historical portraits in Psača and the time of their painting] in Srednovekovnata umetnost vo Makedonija. Freski i ikoni, [Medieval art in Macedonia. Frescoes and icons] ed. Darko Nikolovski (Skopje, 2004), pp. 245-65.

Russo, Vittorio, "Paradiso XIX 140-141: '... e quel di Rascia / che male ha visto (o male aggiustò) il conio di Vinegia," Studi danteschi 54 (1982), 99-111.

Šarkić, Srđan, "Stefan Uroš Milutin - 'Sveti kralj' ili stanovnik Danteovog 'Pakla,'” [Stefan Uros Milutin - The 'Holy King' or a resident of Dante's Hell] Zbornik radova Pravnog fakulteta 37/1-2 (2003), 59-63.

Spatharakis, Ioannis, The Portrait in Byzantine Illuminated Manuscripts (Leiden, 1976). Spremić, Momčilo, Despot Đurađ Branković i njegovo doba [Despot Đurađ Branković and his time] (Belgrade, 1994).

Stahl, Alan M., Zecca: The Mint of Venice in the Middle Ages (Baltimore, 2000).

Stanković, Vlada, Kralj Milutin (1282-1321) [King Milutin (1282-1321)] (Belgrade, 2012).

Stanković, Vlada, "King Milutin and his Many Marriages ( ${ }^{*} 1254$, †November 21, 1321, r. 1282-1321)," in Portraits of Medieval Eastern Europe, 9oo-140o, eds. Donald G. Ostrowski, and Christian Raffensperger (London, 2018), pp. 109-19.

Starodubcev, Tatjana, "Slikari zadužbina Lazarevića," [Painters of the Endowments of the Lazarević dynasty] Zbornik radova Vizantološkog instituta 43 (2006), 349-91. 
Starodubcev, Tatjana, Srpsko zidno slikarstvo u zemljama Lazarevića i Brankovića 1-2 [Serbian wall painting in the lands of the Lazarević and Branković families] (Belgrade, 2016).

Stevović, Ivan, "O prvobitnom izgledu i vremenu gradnje crkve Sv. Mihajla u Stonu," [On the original appearance and construction date of the church of Saint Michael at Ston] Zbornik radova Vizantološkog instituta 35 (1996), 175-95.

Stuard, Susan Mosher, Gilding the Market: Luxury and Fashion in Fourteenth-Century Italy (Philadelphia, 2006).

Subotić, Gojko, and Maksimović, Ljubomir, "Sveti Sava i podizanje Mileševe," [Saint Sava and the construction of Mileševa] in Vizantijski svet na Balkanu 1, [Byzantine world in the Balkans] eds. Bojana Krsmanović, Ljubomir Maksimović, and Radivoj Radić (Belgrade, 2012), pp. 97-106.

Subotić, Gojko, Miljković, Bojan, Špadijer, Irena, and Tot, Ida, Natpisi istorijske sadržine uzidnom slikarstvu. Tom prviXII-XIVvek, [Inscriptiones historicae in picturis muralibus. Tomus primus saeculorum XII-XII] ed. Ljubomir Maksimović (Belgrade, 2015).

The History of Serbian Culture, ed. Pavle Ivić (Edgware, 1995).

Todić, Branislav, Gračanica. Slikarstvo [Gračanica. Wall paintings] (Belgrade, 1988).

Todić, Branislav, Staro Nagoričino (Belgrade, 1993).

Todić, Branislav, "Ktitorska kompozicija u naosu Bogorodičine crkve u Studenici," [Ktetor's composition in the nave of the Virgin's church in Studenica] Saopštenja 29 (1997), 35-45.

Todić, Branislav, Serbian Medieval Painting: the Age of King Milutin (Belgrade, 1999).

Todić, Branislav, "Apostol Andreja i srpski arhiepiskopi na freskama Sopoćana," [Apostle Andrew and Serbian archbishops on the frescoes of Sopoćani] in Papers of the Third Yugoslav Byzantine Studies Conference, eds. Ljubomir Maksimović, Ninoslava Radošević, and Ema Radulović (Belgrade, 2002), pp. 361-79.

Todić, Branislav, "Srpske teme na freskama XIV veka u crkvi sv. Dimitrija u Peći," [Serbian themes in $1^{4 t h}$-century frescoes in the church of Saint Demetrios in Peć] Zograf 30 (2004-05), 123-40.

Todić, Branislav, and Čanak-Medić, Milka, Manastir Dečani [The monastery of Dečani] (Belgrade, 2005).

Todić, Branislav, "Sopoćani i Gradac. Uzajamnost funerarnih programa dve crkve," [Sopoćani i Gradac. About the relation of funerary programmes of the two churches] Zograf 31 (2006-07), 59-76.

Todić, Branislav, "Novo tumačenje programa i rasporeda fresaka u Mileševi," [A new interpretation of the program and layout of murals in Mileševa] in Na tragovima Vojislava J. Đurića, [On the trail of Vojislav J. Đurić] eds. Dejan Medaković, and Cvetan Grozdanov (Belgrade, 2011), pp. 55-68.

Tomić Đurić, Marka, "New Kingdom in the South - Art in the Mrnjavčević State," in Sacral Art of the Serbian Lands in the Middle Ages, eds. Dragan Vojvodić, and Danica Popović (Belgrade, 2016), pp. 367-79. 
Tomić Đurić, Marka, Freske Markovog manastira [The frescoes of Marko's monastery] (Belgrade, 2019).

Toynbee, Paget, A Dictionary of Proper Names and Notable Matters in the Works of Dante (Oxford, 1898).

Trifunović, Đorđe, “Natpisi uz portrete Nemanjića u manastiru Mileševi," [Inscriptions with portraits of Nemanjić in the Mileševa monastery] Književnost i jezik 2-4 (1992), 91-100.

Vasiljević, Marija, "Nastanak srpskih rodoslova i letopisa kao polsedica političkih i društvenih promena," [The emergence of Serbian genealogies and chronicles as a consequence of political and social changes] Initial. A review of medieval studies 3 (2015), 95-117.

Vasiljević, Marija, "Imagining the ruler's genealogy in medieval Serbia," Revue des études sud-est européennes 55 (2017), 73-88.

Veneskey, Laura, "Truth and mimesis in Byzantium: a speaking reliquary of Saint Demetrios of Thessaloniki," Art history 42 (2019), 16-39.

Veselinović, Andrija, Država srpskih despota [State of the Serbian despots] (Belgrade, 2006).

Vojvodić, Dragan, "Portreti vladara, crkvenih dostojanstvenika i plemića u naosu i priprati," [Portraits of rulers, church dignitaries and patricians in nave and narthex] in Zidno slikarstvo manastira Dečana. Građa i studije, [Mural painting of monastery of Dečani. Material and studies] ed. Vojislav J. Đurić (Belgrade, 1995), pp. $265^{-99}$.

Vojvodić, Dragan, "Vladarski portreti srpskih despota," [The sovereign portraits of the Serbian despots] in Manastir Resava. Istorija i umetnost, [Resava Monastery. Its history and art] ed. Vojislav J. Đurić (Despotovac, 1995), pp. 65-98.

Vojvodić, Dragan, "Ktitorski portreti i predstave," [Ktetors' portraits and representations] in Manastir Hilandar, [The monastery of Chilandar] ed. Gojko Subotić (Belgrade, 1998), pp. 249-57.

Vojvodić, Dragan, "Un regard nouveau sur la représentation du Concile de saint Siméon-Nemanja à Arilje," Cahiers balkaniques 31 (2000), 11-20.

Vojvodić, Dragan, "Ukrštena dijadima i 'torakion.' Dve drevne i neuobičajene insignije srpskih vladara u XIV i XV veku," [The crossed diadem and 'thorakion.' Two ancient and unusual insignia of Serbian rulers in the 14th and $15^{\text {th }}$ centuries] in Papers of the Third Yugoslav Byzantine Studies Conference, eds. Ljubomir Maksimović, Ninoslava Radošević, and Ema Radulović (Belgrade, 2002), pp. 249-76.

Vojvodić, Dragan, "Srpski vladarski portreti u manastiru Duljevu," [Portraits of Serbian rulers in the Duljevo monastery] Zograf 29 (2003), 143-6o.

Vojvodić, Dragan, Zidno slikarstvo crkve Svetog Ahilija u Arilju [Wall paintings of the church of Saint Achilleos in Arilje] (Belgrade, 2005).

Vojvodić, Dragan, “'Obavijen zemaljskom slikom.' O predstavama vizantijskih i srpskih srednjovekovnih vladara u proskinezi,” ['Shrouded in earthly image.' On the images 
of Byzantine and Serbian medieval rulers in proskynesis] Crkvene studije 4 (2007), 379-401.

Vojvodić, Dragan, “Od horizontalne ka vertikalnoj genealoškoj slici Nemanjića," [From the horizontal to the vertical genealogical image of the Nemanjić dynasty] Zbornik radova Vizantoloskog instituta 44/1 (2007), 295-312.

Vojvodić, Dragan, "Personalni sastav slike vlasti u doba Paleologa. Vizantija Srbija - Bugarska," [The selection of royal figures in the image of power during the Palaiologan epoch: Byzantium - Serbia - Bulgaria] Zbornik radova Vizantoloskog instituta 46 (2009), 409-33.

Vojvodić, Dragan, “Doslikani vladarski portreti u Gračanici,” [Additionally painted portraits of rulers in Gračanica] Niš \& Byzantium 7 (2009), 251-65.

Vojvodić, Dragan, "Slika svetovne i duhovne vlasti u srpskoj srednjovekovnoj umetnosti," [The image of secular and spiritual authorities in Serbian medieval art] Zbornik za likovne umetnosti Maticerpskee 38 (2010), 35-78.

Vojvodić, Dragan, "Portreti prvih ktitora u prizemlju žičke kule. Poreklo ikonografije," [Portraits of the first donors on the ground floor of the Žiča tower. Origin of the iconography] Niš \& Byzantium 10 (2012), 323-39.

Vojvodić, Dragan, “Rodoslovne predstave i ideja praroditeljstva u manastiru Studenici," [Genealogical representations and the idea of ancestry in the Studenica monastery] in Studenica monastery - 70o years of the King's Church, eds. Ljubomir Maksimović, and Vladimir Vukašinović (Belgrade, 2016), pp. 253-66.

Vojvodić, Dragan, "Ka carskom dostojanstvu kraljevske vlasti: vladarske insignije i ideologija u doba prvih Nemanjića," [Towards the imperial dignity of royal rulership: insignia and ideology under the first Nemanjić rulers] in Kraljevstvo i arhiepiskopija u srpskim i pomorskim zemljama Nemanjića, [The kingdom and the archbishopric of the Serbian and maritime lands of the Nemanjić dynasty] eds. Ljubomir Maksimović, and Srđan Pirivatrić (Belgrade, 2019), pp. 315-54.

Vojvodić, Dragan, "Oružje s nebesa. Ikonologija srednjovekovnih predstava investiture vladara vojnim insignijama," [Weapons from heavens. Iconology of medieval representations of the investiture of rulers by military insignia] in Pristupna predavanja dopisnih članova 1, [Access lectures by correspondent members] ed. Miro Vuksanović (Belgrade, 2019), pp. 237-58.

Živković, Miloš, "Studenica: The Funerary Church of the Dynastic Founder - the Cornerstone of Church and State Independence," in Sacral Art of the Serbian Lands in the Middle Ages, eds. Dragan Vojvodić, and Danica Popović (Belgrade, 2016), pp. 193-209.

Živković, Tibor, Portreti srpskih vladara: IX-XII vek [Portraits of Serbian rulers: 9th-12th centuries] (Belgrade, 20o6). 


\section{Illustrations}

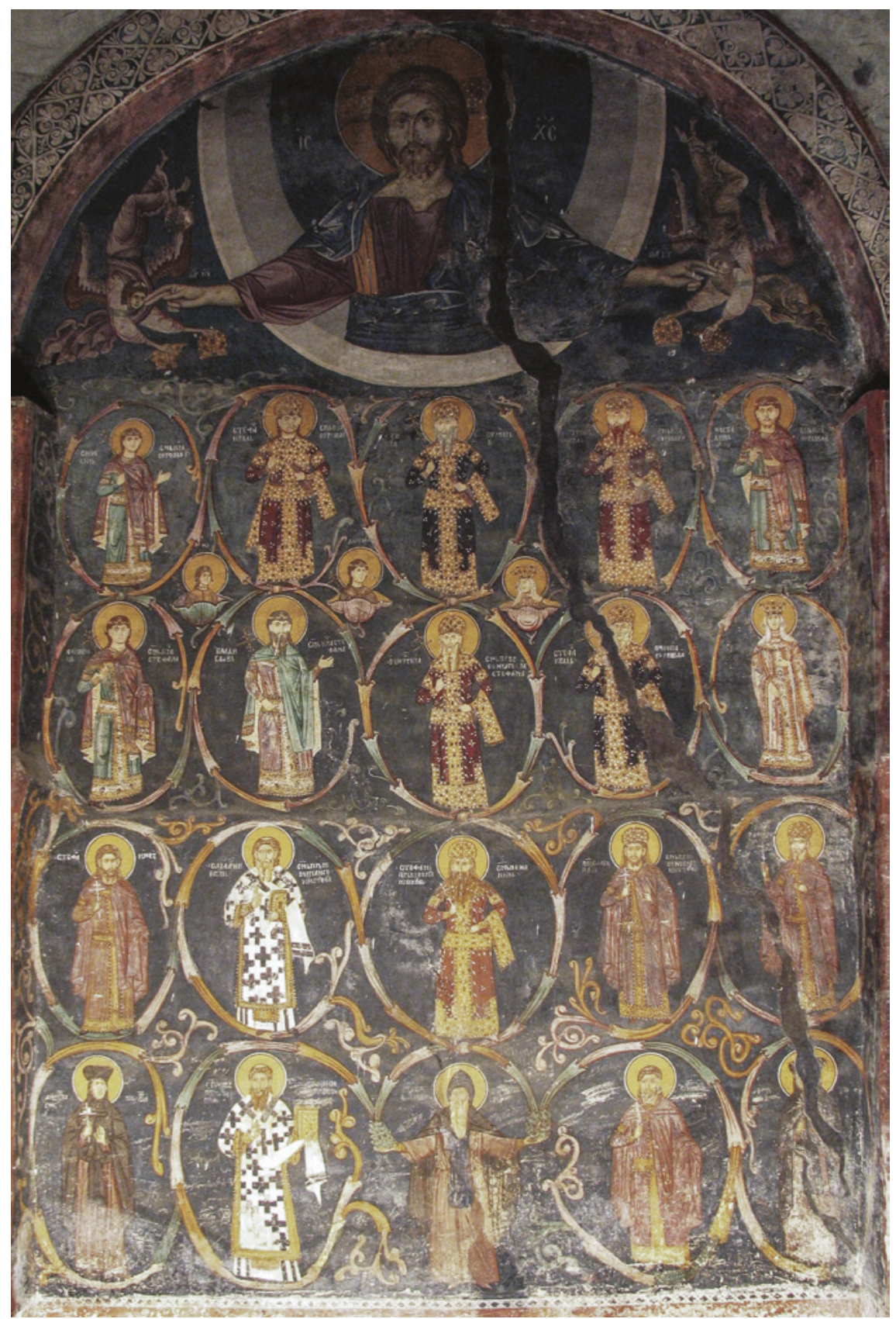

FIGURE 5.1 Nemanjić Family Tree, Peć Patriarchate, $c .1332$

WITH KIND PERMISSION OF THE GALLERY OF FRESCOES, BELGRADE 


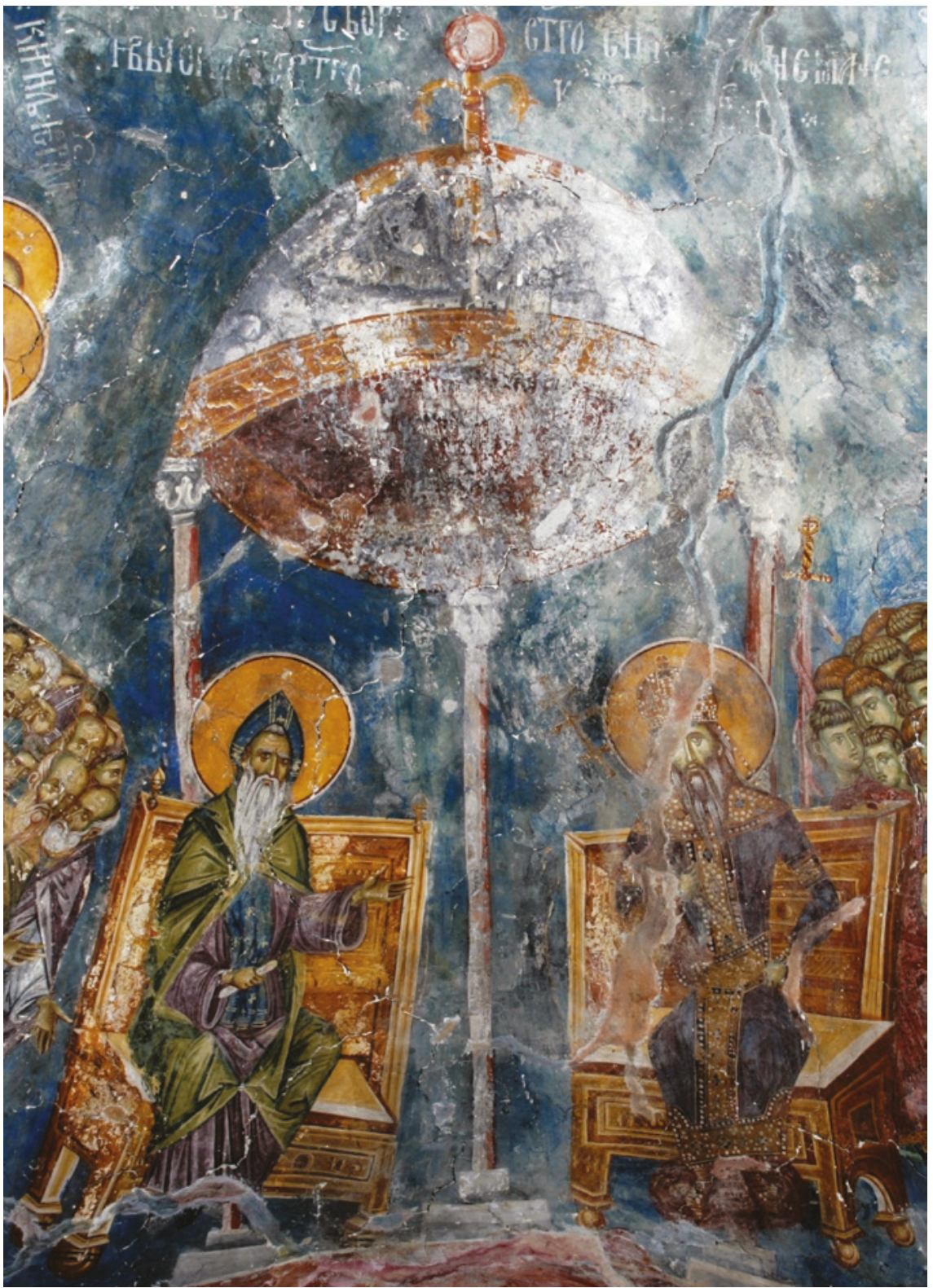

FIGURE 5.2 Synod of St Simeon Nemanja and St King Milutin, Peć Patriarchate, c. 1324 WITH KIND PERMISSION OF THE GALLERY OF FRESCOES, BELGRADE 


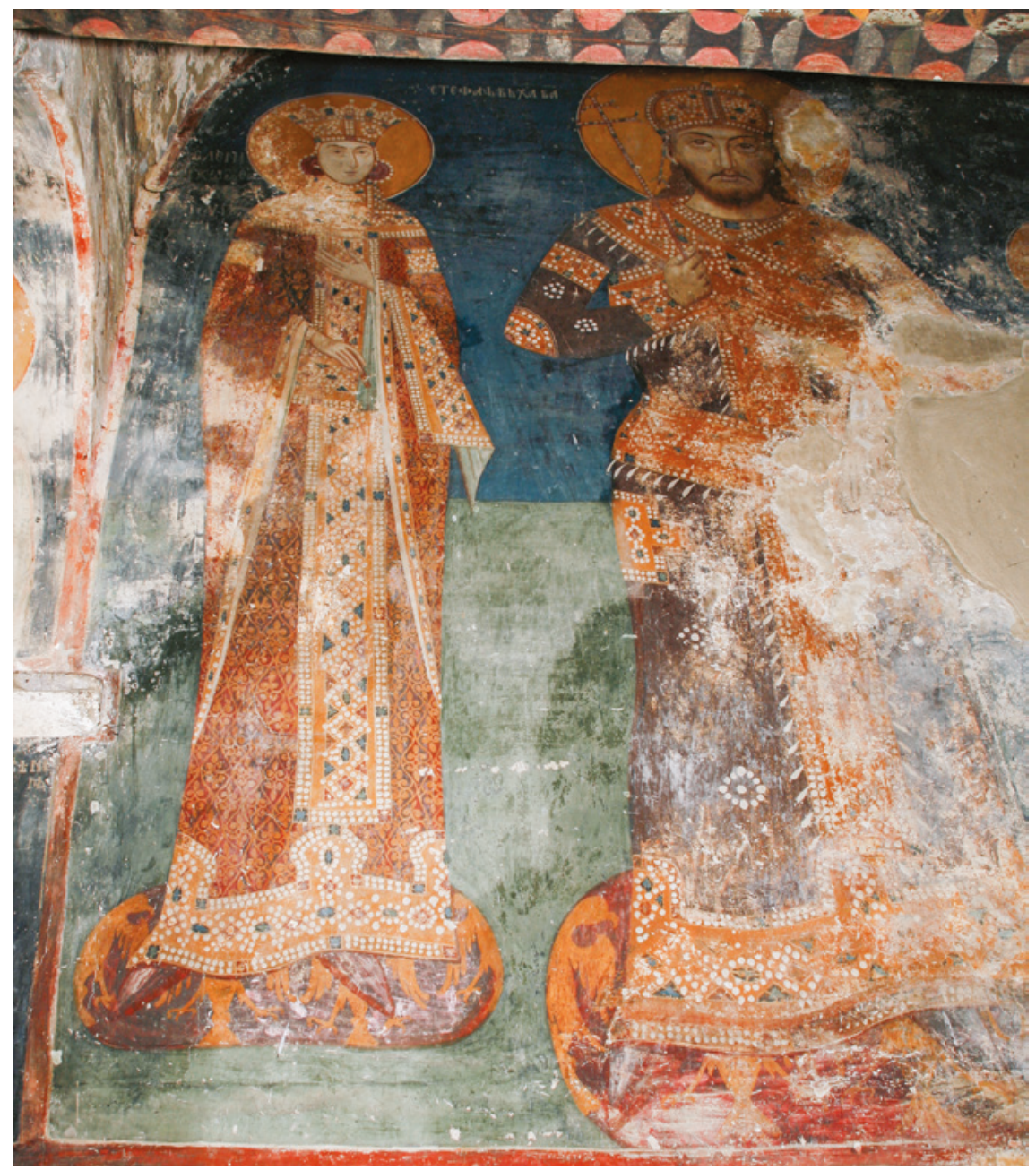

FIGURE 5.3 Tsar Stefan Uroš IV Dušan and Augusta Jelena, Lesnovo, 1349 WITH KIND PERMISSION OF THE GALLERY OF FRESCOES, BELGRADE 


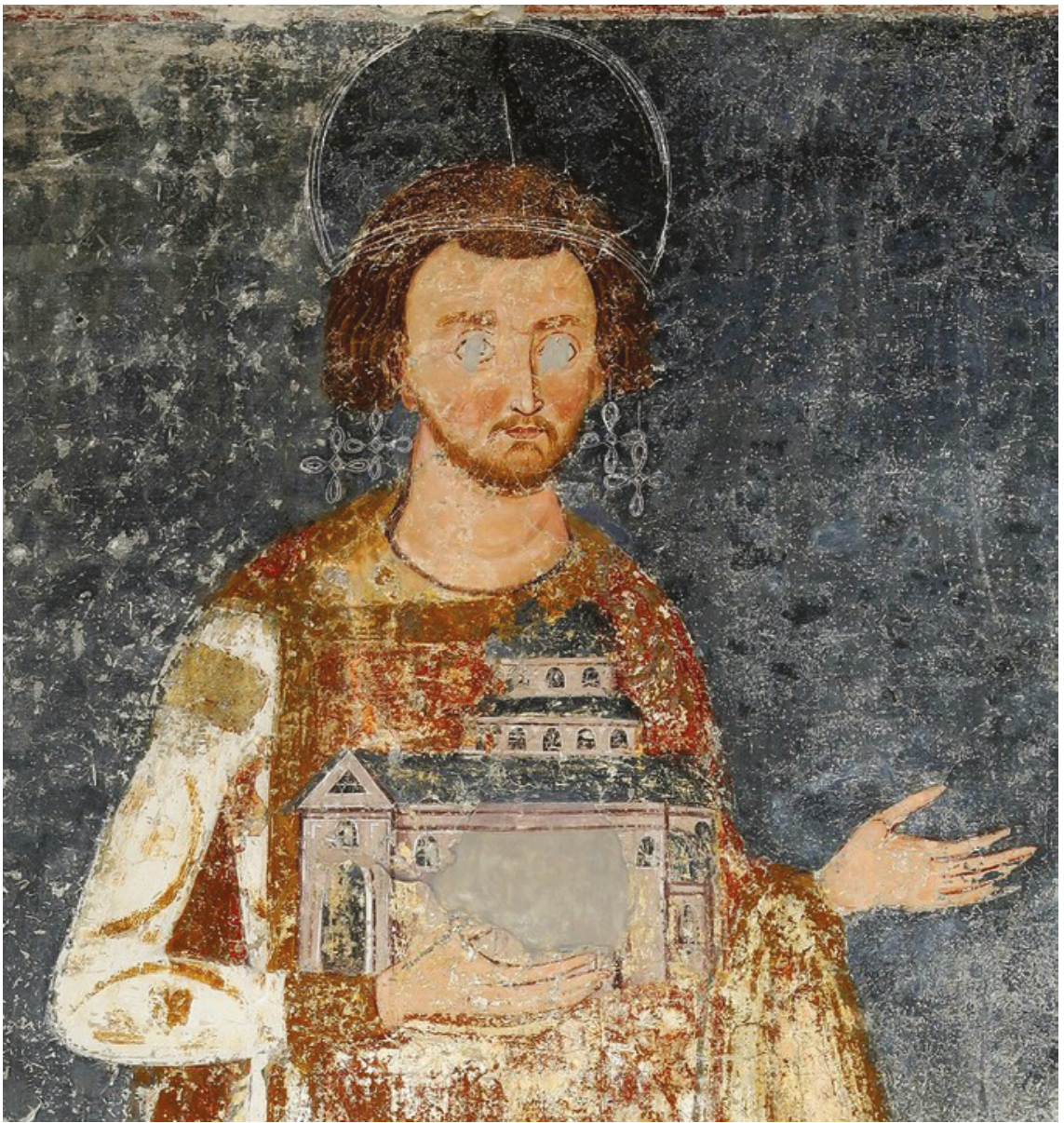

FIGURE 5.4 Prince Vladislav, Mileševa, c. 1225 (with crown added $c .1235$ ) WITH KIND PERMISSION OF THE GALLERY OF FRESCOES, BELGRADE 


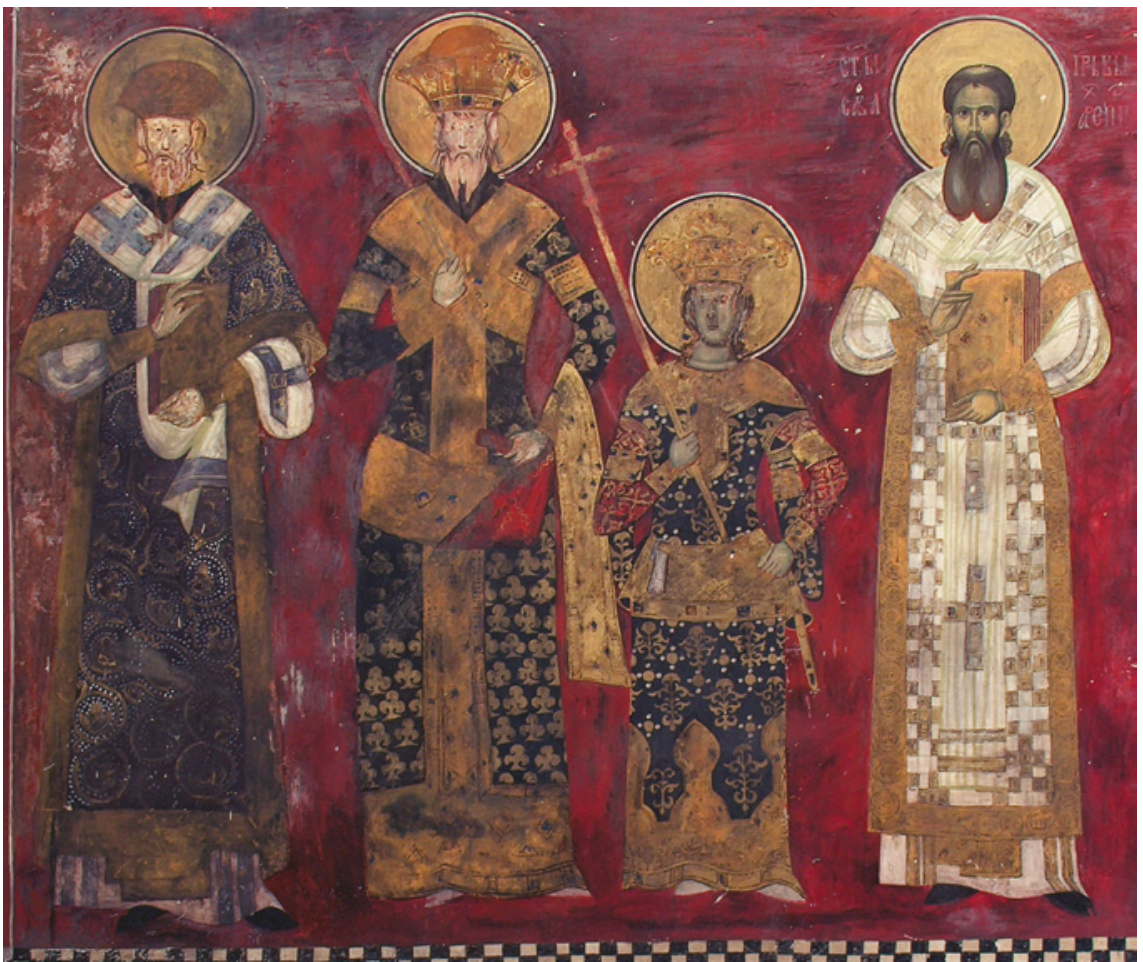

Figure 5.5 Archbishop Nikodim, King Stefan Uroš III, Prince Dušan, St Sava the Serbian, Peć Patriarchate, $c .1324$

WITH KIND PERMISSION OF THE GALLERY OF FRESCOES, BELGRADE 


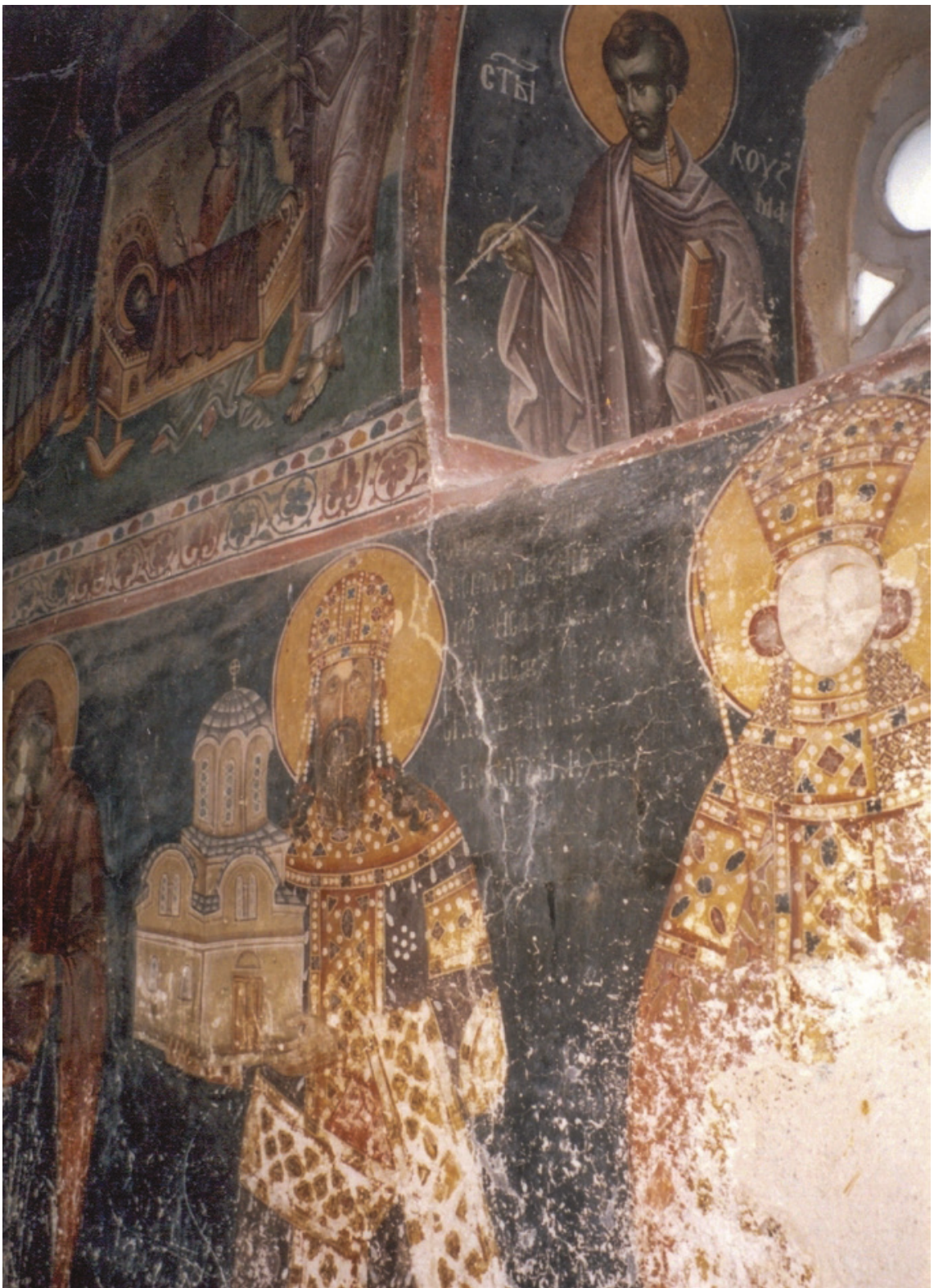

FIGURE 5.6 King Stefan Uroš II Milutin and St Cosmas, Studenica, 1314/18 WITH KIND PERMISSION OF THE MONASTERY STUDENICA, PHOTOGRAPH BY BRANISLAV CVETKOVIĆ 


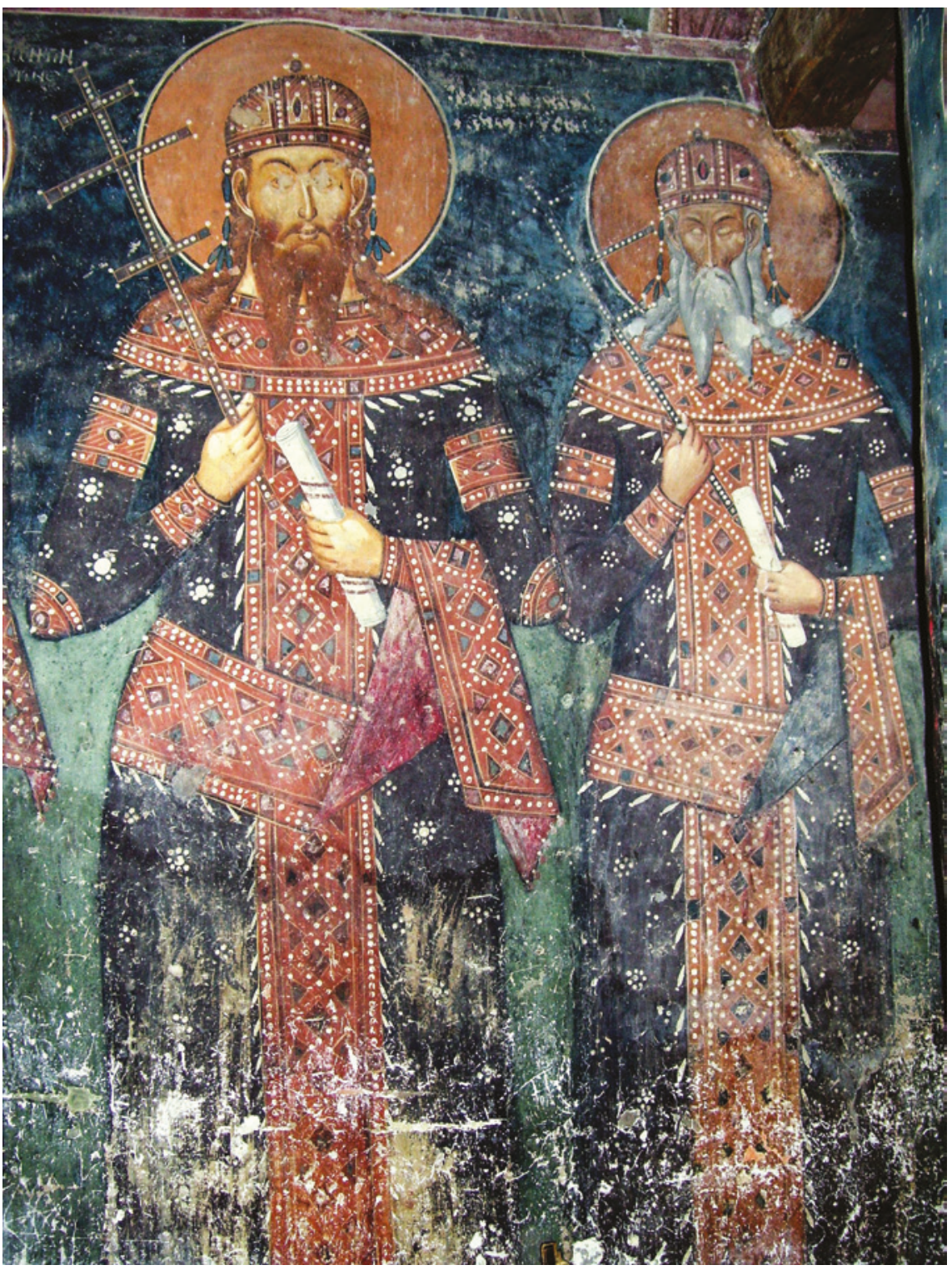

FIGURE 5.7 Tsar Stefan Uroš V and King Vukašin, Psača, c. 1365/71 WITH KIND PERMISSION OF THE GALLERY OF FRESCOES, BELGRADE 


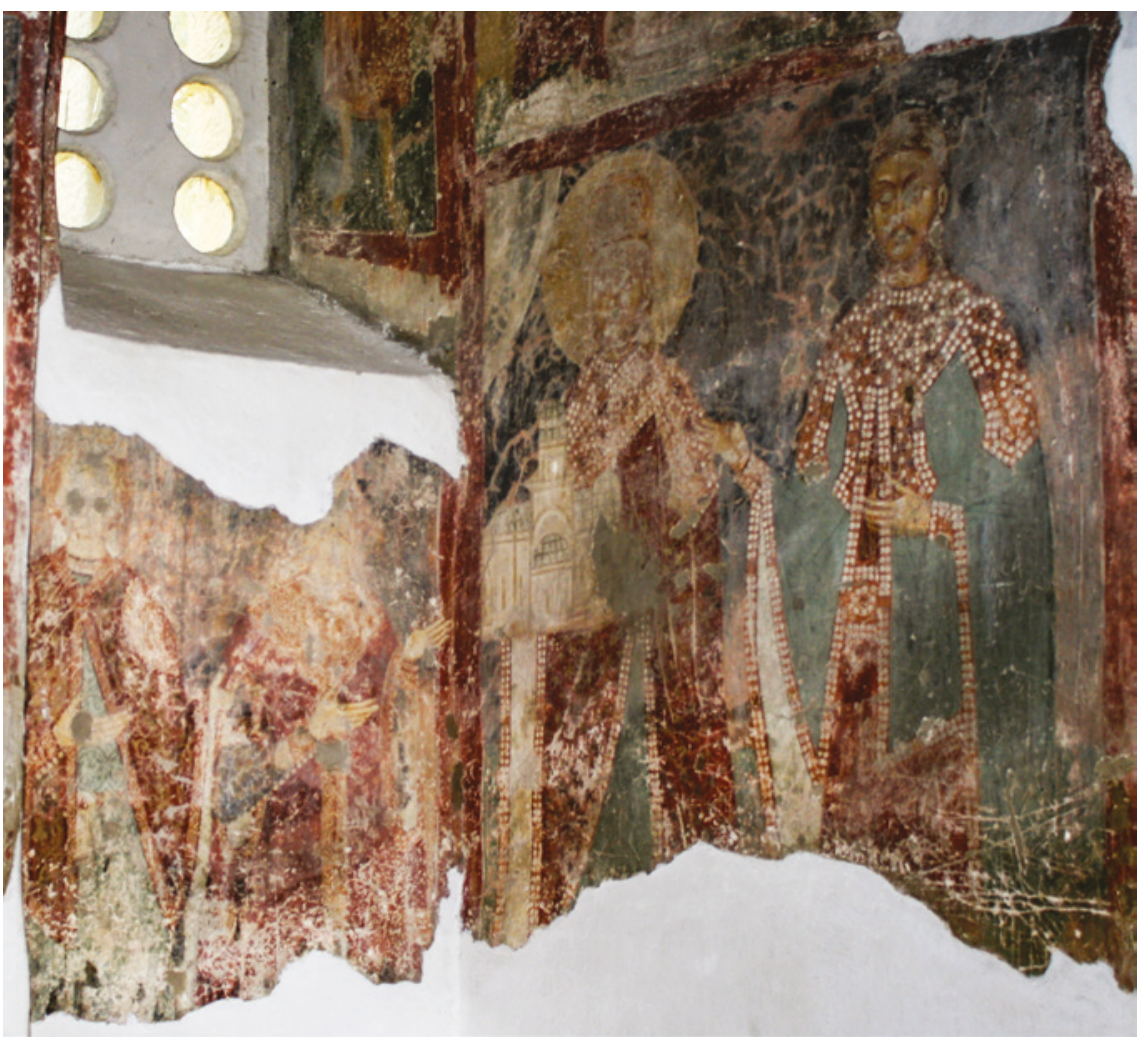

FIGURE 5.8 Despot Stefan and lord Vuk with two nobles, Rudenice, c. 1405

WITH KIND PERMISSION OF THE MONASTERY RUDENICE, PHOTOGRAPH BY BRANISLAV CVETKOVIĆ 


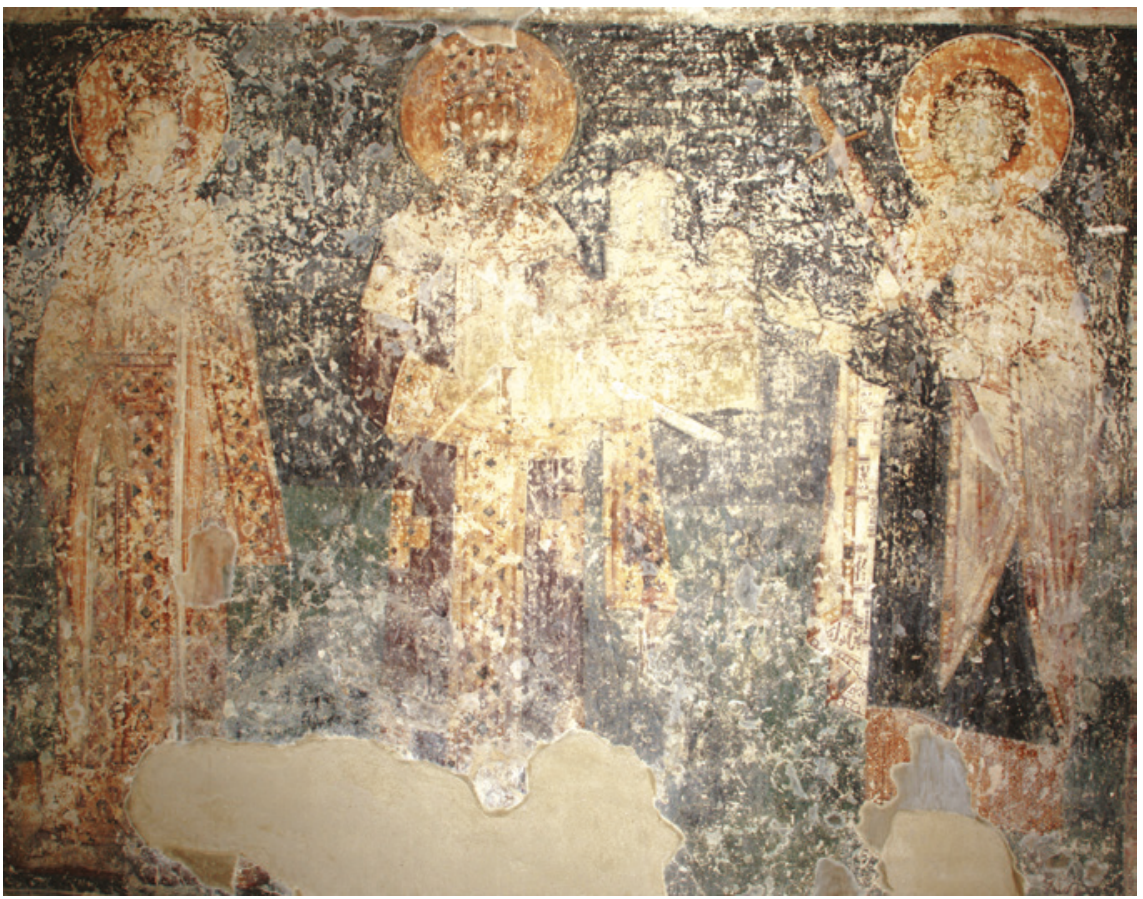

FIGURE 5.9 Queen Simonis, King Milutin and St George, Staro Nagoričino, 1318 WITH KIND PERMISSION OF THE GALLERY OF FRESCOES, BELGRADE 


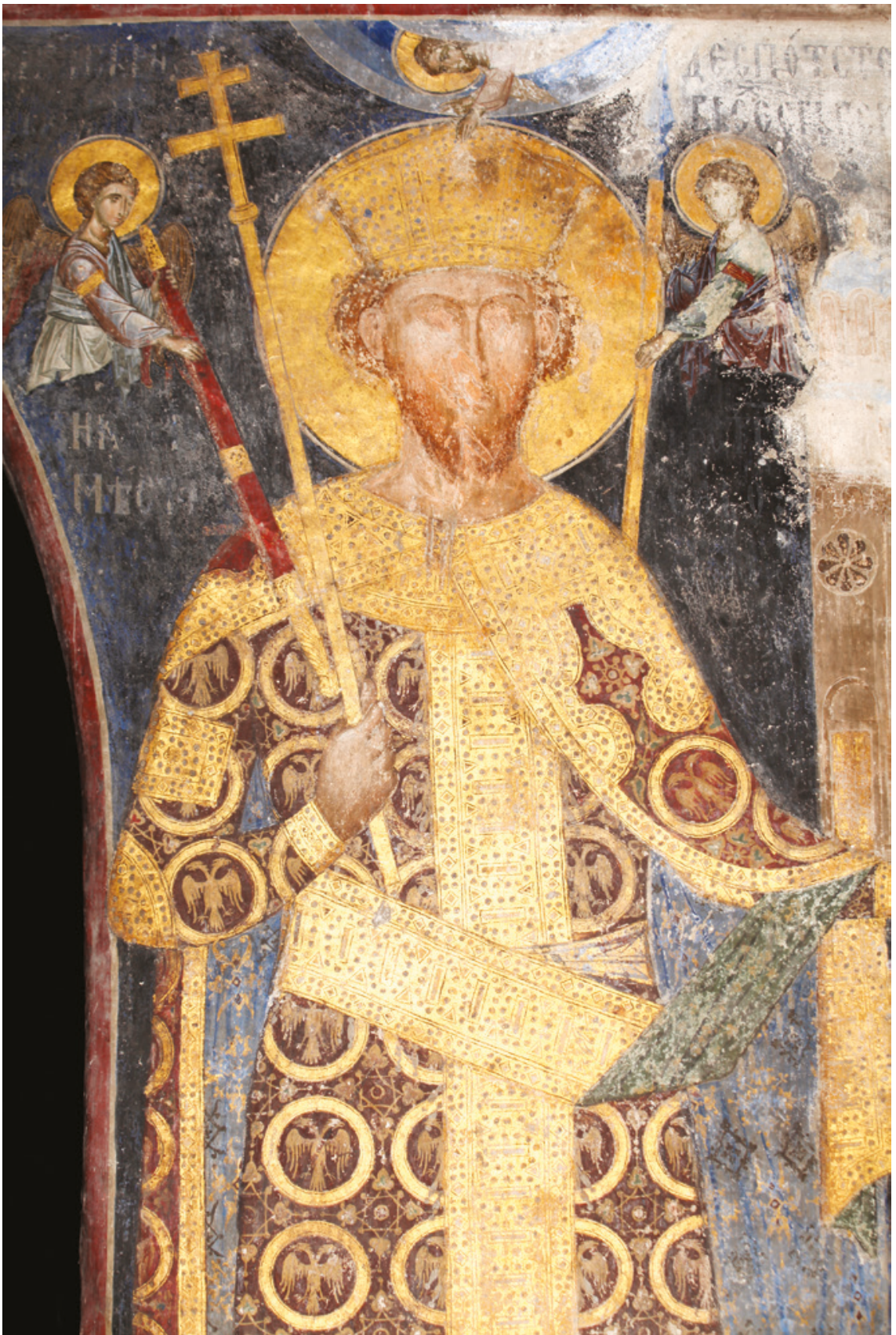

FIGURE 5.10 Despot Stefan Lazarević, Resava, 1418 WITH KIND PERMISSION OF THE REPUBLIC INSTITUTE FOR PROTECTION OF THE MONUMENTS OF CULTURE, BELGRADE 